\title{
The city of Hartapu: results of the Türkmen-Karahöyük Intensive Survey Project
}

\author{
James F. Osborne, ${ }^{1}$ Michele Massa, ${ }^{2}$ Fatma Şahin, ${ }^{3}$ Hüseyin Erpehlivan ${ }^{4}$ \\ and Christoph Bachhuber ${ }^{5}$
}

\author{
${ }^{1}$ University of Chicago, USA, ${ }^{2}$ British Institute at Ankara, UK, ${ }^{3}$ Çukurova University, Turkey, \\ ${ }^{4}$ Bilecik University, Turkey, and ${ }^{5}$ University of Oxford, UK \\ jamesosborne@uchicago.edu
}

\begin{abstract}
The Türkmen-Karahöyük Intensive Survey Project (TISP) has identified the archaeological site of Türkmen-Karahöyük on the Konya plain as a previously unknown Iron Age capital city in the western region of Tabal. Surface collections and newly discovered inscriptional evidence indicate that this city is the early first-millennium royal seat of 'Great King Hartapu', long known from the enigmatic monuments of nearby Kızıldağ and Karadağ. In addition to demonstrating this Iron Age city's existence, supported principally by (1) the site's size at the time and (2) the discovery of a royal inscription authored by Hartapu himself, TISP has documented the site's existence from the Late Chalcolithic period until the late first millennium BCE, with a maximum size reached between the Late Bronze and Iron Age periods, suggesting that the city was at its greatest extent and the regional political centre from at least the late second to the mid-first millennium BCE.
\end{abstract}

\section{Özet}

Türkmen-Karahöyük Yoğunlaştırılmış Yüzey Araştırması Projesi (TISP), Konya Ovası'nda yer alan Türkmen-Karahöyük arkeolojik yerleşmesini Tabal bölgesinin batısında konumlanmış ve daha önceden bilinmeyen bir Demir Çağı merkezi olarak tanımlamaktadır. Yüzey seramikleri ve yeni keşfedilen yazılı kanıtlar göstermektedir ki kent erken birinci binyılda, ismi uzun süredir Kızıldağ ve Karadağ'daki gizemli anıtlardan bilinen Kral Hartapu'nun krallı̆̆ının merkezidir. Demir Çă̆ı kentinin varlı̆̆ının kanıtlanmasına ek olarak, yerleşmenin dönemsel boyutları (1) ve Hartapu'nun kendisi tarafindan yazdırılmış bir kraliyet yazıtının keşfi (2), TISP tarafından belgelenen Geç Kalkolitik Dönem'den geç birinci binyıla kadar yerleşimin varlığını sürdürmesi arasında, Geç Tunç Çağı ve Demir Çağı'nda en geniş boyutlarına ulaşması ile desteklenmesinin ardından, kentin en geniş boyutlarındayken yani geç ikinci binyıldan, birinci binyılın ortalarına kadar bölgesel bir merkez olduğu önerilmektedir.

$\mathrm{T}$ he Türkmen-Karahöyük Intensive Survey Project (TISP), directed by James Osborne, began in the summer of 2019 as a single-site survey under the umbrella of a larger regional survey, the Konya Regional Archaeological Survey Project (KRASP) directed by Michele Massa and Christoph Bachhuber. Building on the results of previous archaeological surveys in the region, KRASP had quickly identified over 100 sites of all periods, including many that were clear candidates for more sustained exploration (see Massa et al. 2020, this volume). Among these was the site of Türkmen-Karahöyük, a large mound adjacent to the modern village of the same name and situated at the northern edge of the now-vanished

Hotamış lake (fig. 1). KRASP first visited the site in 2017, and a semi-intensive survey in 2018 recognised its importance as the largest Bronze and Iron Age settlement mound in the region (Massa et al. 2019: 168). At the invitation of KRASP, TISP was initiated by Osborne on behalf of the University of Chicago's Oriental Institute in collaboration with KRASP. Fieldwork took place at TürkmenKarahöyük in June to July 2019. Although there is more work to be done at the site (see 'Discussion and conclusion', below), the remarkable discoveries made in this first field season warrant immediate publication in order to share the results with the scholarly community as promptly as possible. 


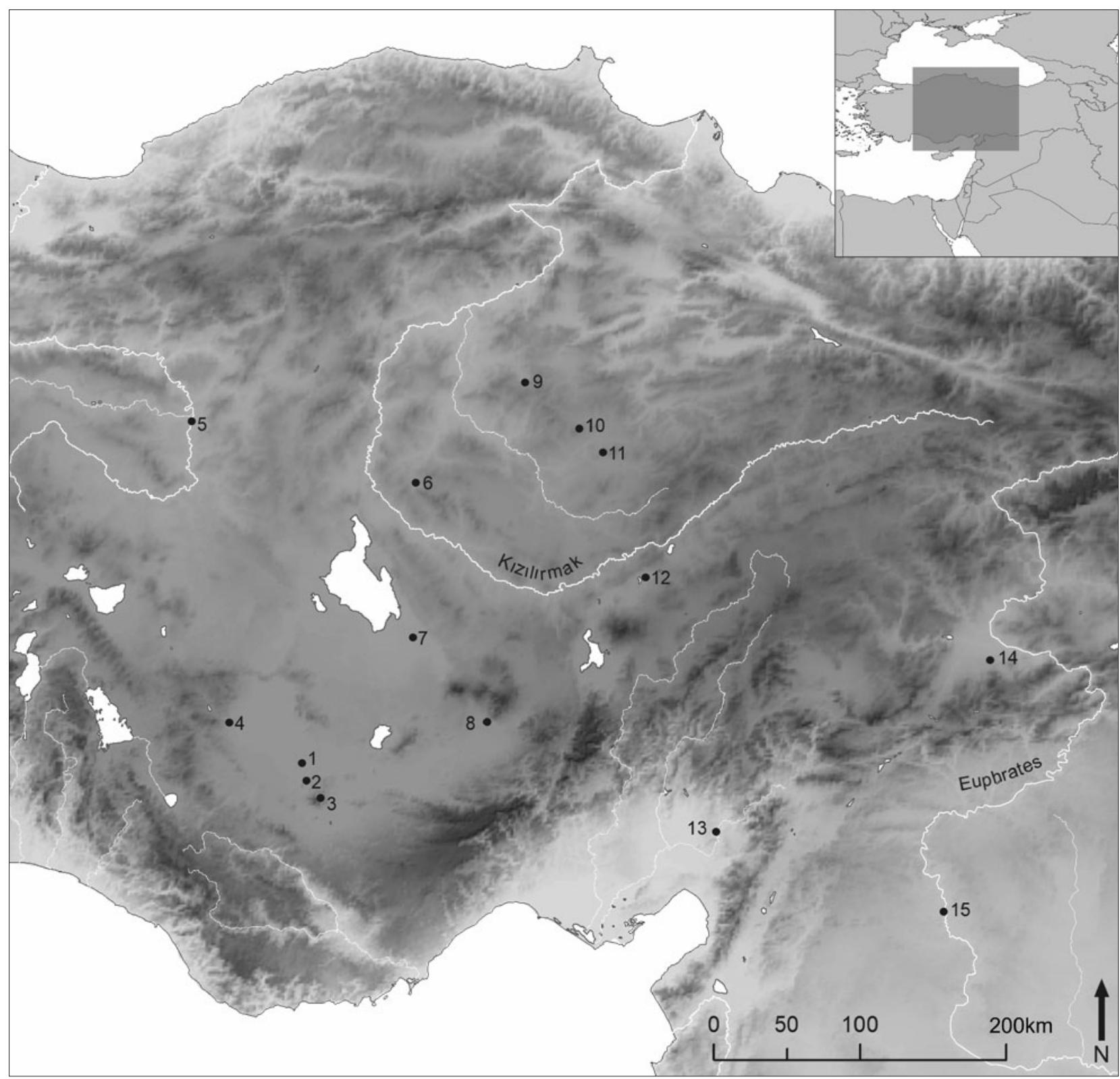

Fig. 1. Map of sites mentioned in the article. 1 Türkmen-Karahöyük; 2 Kızıldăg; 3 Karadăg; 4 Konya-Karahöyük; 5 Gordion-Yassıhöyük; 6 Kaman Kalehöyük; 7 Acemhöyük; 8 Kınık Höyük; 9 Hattuša-Boğazköy; 10 Kerkenes Dă̆; 11 Alişar Höyük; 12 Kültepe-Kanesh; 13 Karatepe; 14 Malatya; 15 Carchemish.

The research questions posed by TISP are straightforward. Although the Konya plain has long been well known for prehistoric excavations at sites like Pınarbaşı (Baird et al. 2011), Boncuklu Höyük (Baird et al. 2017), Çatalhöyük (Hodder 2005; 2014) and nearby Can Hasan (French 1998; 2005), Bronze and Iron Age archaeology in the region has received far less attention, despite the evidence, for example, of complex political formations demonstrated by the palaces of Konya-Karahöyük that date to the Old Assyrian Trading Colony period of the early second millennium BCE (Alp 1968). Likewise, historical sources inform us that this area was very likely within the territory of the Late Bronze Age kingdom of Tarhuntašša, rival of the Hittite
Empire, as well as a component of the Iron Age kingdoms of Tabal. One research objective of TISP, therefore, is to situate Türkmen-Karahöyük within the political context of the area in order to clarify the historical trajectory of this under-studied region of Anatolia. Closely related to this goal is the urgent need to understand better the dynamics of cities in southern Turkey following the appearance of urbanism in the late third and early second millennia. Until now there has been almost no awareness of even the existence of major Bronze to Iron Age cities in southern Anatolia beyond Konya-Karahöyük, let alone their urban morphologies and spatial configurations, developments through time and material culture (Matessi, Tomassini Pieri 2018). 
While KRASP is addressing these issues and others at a regional scale (cf. Massa et al. 2020, this volume), TISP offers a detailed look at a single urban centre, one that dominated the southern portion of the Konya plain and the surrounding area for much of the Bronze and Iron Ages. Indeed, lack of knowledge about the region generally and the site of Türkmen-Karahöyük specifically during these periods is so stark that within a few weeks of survey TISP was able to identify Türkmen-Karahöyük as a previously unknown Iron Age capital city. This city was almost certainly the early first-millennium royal seat of 'Great King Hartapu', who likely ruled during the mid- to late eighth century BCE and whose name has long been known from the inscriptions found at the nearby Kızıldağ outcrop and Karadağ volcano (Hawkins 2000: 433-41). This identification is supported by two primary lines of evidence detailed below: first, the site's size at the time, when it possibly reached a staggering 125 ha or more, and, second, the discovery of a royal inscription authored by Hartapu himself. In addition, TISP has documented the site's occupation from the Late Chalcolithic period until the late first millennium BCE, with its maximum extent first reached in the Late Bronze Age and sustained throughout the midfirst millennium, followed by a retraction to the höyük itself at the end of the Iron Age.

After a description of the historical context of Türkmen-Karahöyük and previous research conducted there, this paper describes the site's morphology and TISP's survey methods and findings, including the periodisation of Türkmen-Karahöyük, site size by period, ceramics and small finds, and the discovery and context of the Hartapu inscription.

\section{Background}

As described in greater detail in the article by Massa et al. in this volume, Türkmen-Karahöyük is situated in the midst of an enormously rich archaeological landscape supported by the agricultural potential offered by the alluvial Konya plain. In brief, Türkmen-Karahöyük sits on Late Quaternary lake sediments on the eastern edge of the alluvial fan created by the Çarşamba river and on the northern edge of a small seasonal wetland area related to the now-lost Hotamış lake (Kuzucuoğlu 2019: figs 17.1, 17.3). Despite an extremely dry climate, water sources like the Çarşamba and ancient water-management strategies identified by KRASP have created an agriculturally productive region that has been densely occupied across all periods.

For the purposes of this study, the third to mid-first millennium $\mathrm{BC}$ is the most significant culture-historical period. Early Bronze Age (ca 3200-2000 BCE) remains from the large sites of Alaeddin Tepesi and KonyaKarahöyük, within and on the southern edge of the modern city of Konya respectively, have scarcely been published.
It is therefore difficult to situate the region within interregional trade networks (Şahoğlu 2005; Efe 2007; Massa, Palmisano 2018) or the rise of social complexity in Anatolia during this period (Bachhuber 2015). The same is true of the early second millennium, or Middle Bronze Age (ca 2000-1650 BCE), which witnessed the rise of the Old Assyrian Trading Colony period that is so dramatically attested by the archives and archaeological findings at Kültepe (see Atici et al. 2014 with references). The Konya plain is mostly excluded from discussions of this trade network for lack of evidence, despite a number of large contemporary sites identified by KRASP and previous surveys (Barjamovic 2011: 405). The two major routes of the Assyrian trade network both seem to have stayed north of the Konya plain (Barjamovic 2019: 72-73), and Gojko Barjamovic has recently proposed that the plain was involved in a separate regional system of commerce altogether, perhaps a network based out of Ebla instead of Assur (2019: 75-78). The only excavated site belonging to the Middle Bronze Age is Konya-Karahöyük, today located on the southern outskirts of the modern city. Monumental structures are well preserved but insufficiently published, and no texts have been found to situate the site concretely within the Assyrian trade network; thus the discovery of significant Middle Bronze Age remains by TISP, including Colony period ceramics, is a major contribution to scholarship on this period.

The Konya plain does appear in the historical records of the Late Bronze Age (ca 1650-1200 BCE), when central Anatolia was dominated by the Hittite Empire. Hittite texts describe the plain as a part of the Lower Land, the Hulaya River Land and the kingdom of Tarhuntašša, although the precise borders of these entities on the ground and their semantic relationships with one another have long been debated (d'Alfonso 2014; Matessi 2016; Forlanini 2017). In this context, too, the discovery of TürkmenKarahöyük's extent during the Late Bronze Age will substantially increase our awareness of the importance of southern Anatolia at the time.

Tabal is the term used for the political formations of south-central Anatolia in the Iron Age. Tabal and its constituent polities have long occupied a murky status in Near Eastern scholarship due to our general ignorance, but in broad strokes it seems to have belonged to what may be termed the Syro-Anatolian Culture Complex, or SACC, a collection of diverse polities that surrounded the northeastern corner of the Mediterranean Sea in the late second and early first millennia BCE, including Que, Carchemish, Melid and many others (Osborne forthcoming). 'Tabal' itself has yet to appear in any native Anatolian inscriptions (d'Alfonso 2012). Rather, it is found exclusively in NeoAssyrian royal inscriptions and a small number of references in the Hebrew Bible. In Neo-Assyrian usage, Tabal 
alternates between a geographic term designating a region west of the Euphrates occupied by 24 kings during the reign of Shalmaneser III (r. 858-824 BCE), to an actual kingdom during the reign of Tiglath-pileser III (r. 745-727 $\mathrm{BCE}$ ) a century later, back to a geographical reference during the reign of Sargon II (r. 721-705 BCE) (d'Alfonso 2012: 175-81; Akçay 2014; Şenyürt, Akçay 2018). During Sargon's reign, Tabal was frequently associated with Muški ('[vom] Land Tabāl bis hin zum Land Muški': Fuchs 1994: 313), suggesting that, at this time, Tabal referred to a region further west, such as the Konya plain, and that Tabal and Muški were paired in the Assyrian imagination as the dominant geopolitical players of the era.

Native Hieroglyphic Luwian inscriptions cluster geographically in the region between the Kizilirmak and the Taurus mountains, and chronologically in the eighth century (Hawkins 2000: 425-33; cf. a new dating of the TOPADA inscription in d'Alfonso 2019), but the historical information these provide is not rich (Bryce 2012: 142-53). A smaller group of inscriptions referred to as the 'western group' by David Hawkins should perhaps instead be considered the 'Hartapu group' (Akçay 2016), since they are all inscriptions authored by Hartapu; two locations are indeed quite far west and overlook the Konya plain - those of KIZILDAĞ 1-5 and KARADAĞ 1-2 - and one, that of BURUNKAYA, is in fact much further east and surrounded by inscriptions written by others. These texts directly concern this study, since TISP's discovery of the inscription TÜRKMEN-KARAHÖYÜK 1, also authored by Hartapu, has the potential to shed light on the longstanding chronological and historical debates surrounding this enigmatic corpus (see 'Discussion and conclusion', below).

The reason the Hartapu group of inscriptions has been so stubbornly inscrutable is primarily because of the lack of accompanying archaeological research, a problem that is found across the region of Tabal, as Sanna Aro (2003) has argued. Thus, whilst the Kızıldağ monuments were originally published over a century ago (Ramsay, Bell 1909: 507-12), systematic exploration of the archaeological remains at Kizıldağ has only fairly recently begun (Karauğuz et al. 2002). There has been no excavation of an Iron Age site on the Konya plain beyond poorly understood soundings at Alaeddin Tepesi (Akurgal 1955: Taf. 22; Mellaart 1955: 115-16; Bahar 2019: 210-11, figs 1, $4)$. The nearest excavated sites in central Anatolia are Kınık Höyük (Highcock et al. 2015) and Zeyve Höyük (Dupré 1983), located approximately $125 \mathrm{~km}$ northeast and $135 \mathrm{~km}$ east of Türkmen-Karahöyük, respectively. Kilise Tepe is roughly the same distance to the south (Postgate, Thomas 2007). These sites do have ceramic parallels with Türkmen-Karahöyük (see below), but do not yet have broad horizontal exposure of Iron Age remains that can speak directly to cultural and political developments on the Konya plain. Other excavations are located even further afield, including those at Kaman Kalehöyük, at other sites within the bend of the Kızılırmak, like Alişar Höyük and Kerkenes Dağ, and at Gordion. TürkmenKarahöyük, therefore, finds itself with no immediate neighbour for close Iron Age comparisons.

Previous work at Türkmen-Karahöyük has been restricted to several surveys that have taken place on the Konya plain over the course of the past 75 years (see Massa et al. 2020, this volume), but descriptions of the site are curiously understated or entirely absent. James Mellaart's publications on his survey of the plain in the early $1950 \mathrm{~s}$ only indirectly mention it. In his final report on secondmillennium sites a 'Kara Höyük' in the Ereğli district appears briefly as 'worth mentioning as [a] substantial site' (Mellaart 1958: 318), a reference possibly (and erroneously?) corresponding to the Türkmen-Karahöyük of the present study, which is accurately noted on that publication's site map as site '42. Kara H.' but not otherwise described. Instead, it is 'the monstrous site' of Domuzboğazliyan Höyük and 'the large mound' of Konya-Karahöyük that are singled out for their uniquely great size (1958: 316), an assessment followed by Semih Güneri (1987: 78). Publications deriving from a mound survey in the region conducted in 1958 by Mellaart, A.S. Hall and David French do not discuss the site explicitly (for example French 1970). Neither is Türkmen-Karahöyük mentioned directly in the survey reports of Hasan Bahar or Douglas Baird, although the latter does refer to an unnamed 'large (ca. 40ha) Iron Age site which dwarfs all the others we have investigated to date and must be seen as the major Iron Age centre within the survey area' (Baird 1999: 14). Related studies like A.M. Dinçol's ground reconnaissance of the kingdom of Tarhuntašša or Güngör Karauğuz's preliminary survey of Kızıldağ completely miss the massive höyük, even while apparently passing right by it (Dinçol et al. 2000; Karauğuz et al. 2002). In the latter publication, the modern village of Türkmen-Karahöyük is illustrated on a detailed contour map of Kızıldağ but the höyük is not indicated, even though it towers over the village (Karauğuz et al. 2002: levha II). Not until KRASP conducted an extensive survey of the site in 2018 was Türkmen-Karahöyük recognised for its importance and longevity, and properly presented as such in print (Massa et al. 2019: 168, fig. 13a, table 2).

Scholarship's near-complete ignorance of TürkmenKarahöyük is all the more remarkable given the site's truly massive scale. The höyük rises about $35 \mathrm{~m}$ above the surrounding plain and is visible from many kilometres away in all directions across the valley surface (fig. 2). In area, the höyük measures approximately 30 ha or slightly less, depending on where exactly one considers the höyük to stop and the valley floor to begin. The mound's shape is ovoid and it is oriented almost precisely north-south (fig. 3). It 


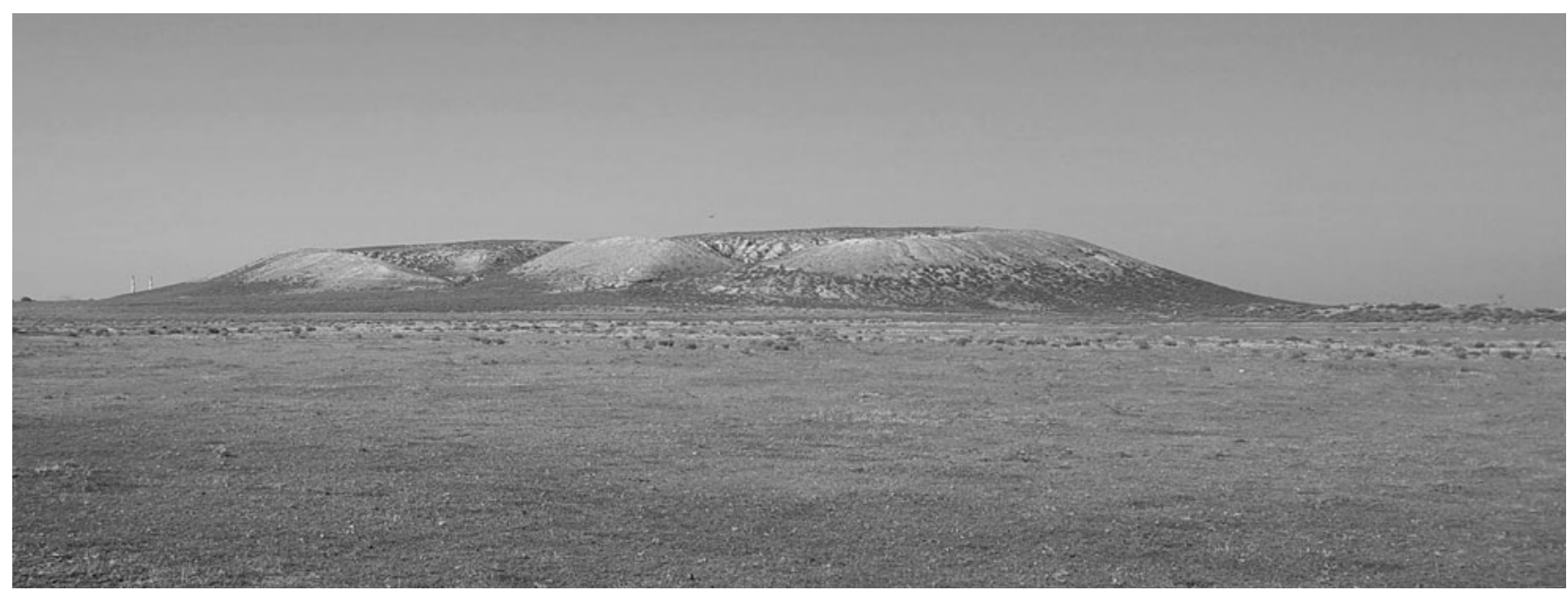

Fig. 2. View of Türkmen-Karahöyük from the northeast (photograph by James Osborne).

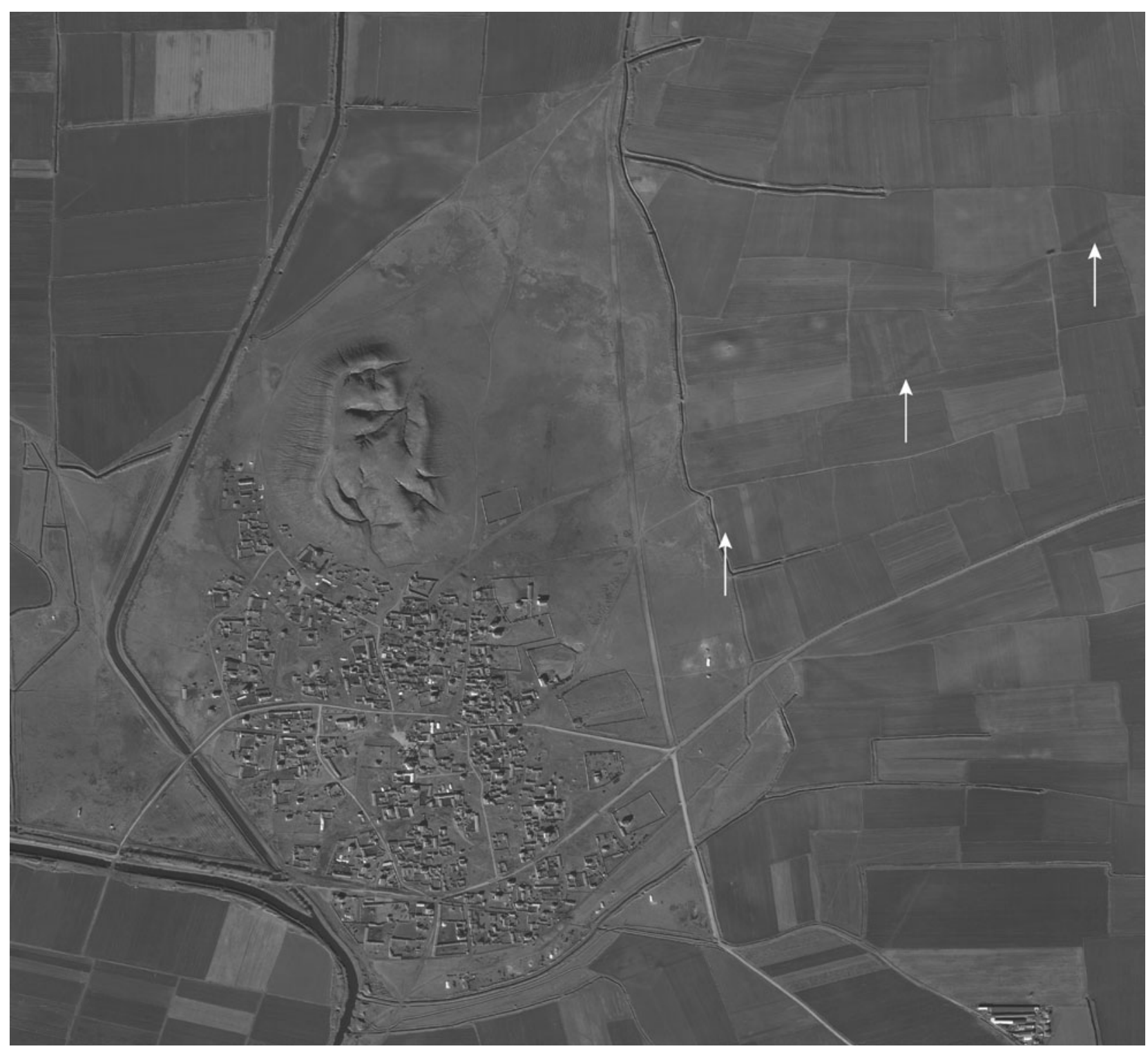

Fig. 3. Digital Globe satellite image of Türkmen-Karahöyük. Arrows mark a hollow way heading northeast out of the lower town in the direction of Büyük Aşlama Höyük. Directly north of the westernmost arrow is a small tumulus visible on the ground, with two additional tumuli to its east visible only in satellite imagery. 
does not have an even topography, however. A 3.5m-wide mudbrick fortification wall, visible in profile in many segments around the eastern summit of the mound and dating to the Late Iron Age or later, has preserved the western half of the summit's circumference. The eastern side, however, is characterised by several long and deep gullies that can reach well over $150 \mathrm{~m}$ in length. These can only have been created by breaches in the fortification system eroding more quickly than other areas of the wall over time, and thus are perhaps indicators of gateway locations. That the ancient settlement may indeed have been more oriented toward the east than the west is supported by the presence of a hollow way extending out from the lower town's eastern edge toward the northeast for a visible distance of roughly $2 \mathrm{~km}$ (see fig. 3); this is morphologically similar to the better-preserved hollow-way systems of northern Mesopotamia (Ur 2003). To the east of the höyük is a large patch of uncultivated land used as pasture by the villagers who live in modern Türkmen-Karahöyük, immediately south of the mound.

A digital elevation model (DEM) of the entire site including the lower town is currently being created by means of an unmanned aerial vehicle survey using a DJI Phantom 4 drone and Agisoft photogrammetry software. Preliminary results clearly show topographic rises in the outer lower town, approximately 600-700m north and east of the höyük. Just beyond these rises to the east lies a low and small tumulus, with others visible in the satellite imagery (fig. 3).

\section{The TISP survey}

The methods employed by TISP develop those used by the Tayinat Lower Town Project (Osborne 2017; Osborne and Karacic 2017), which themselves were borrowed from Jason Ur's Tell Brak Suburban Survey (Ur et al. 2011) and Tell Hamoukar Survey (Ur 2010); these latter two sites are of similar size and comparable geomorphological conditions to Türkmen-Karahöyük. Unlike the Brak and Tayinat surveys, however (but like the Hamoukar survey), TISP included the höyük in its collection area, since there has been no excavation of the site; the surface materials thus remain undisturbed, and the nature of the mound's occupation is as unclear as that of the lower city.

Unlike intensive survey at smaller settlements, such as Çaltılar Höyük where complete coverage is attainable (Momigliano et al. 2011), the vast scale of TürkmenKarahöyük requires TISP to use a probabilistic systematic sampling strategy to obtain a statistically valid estimate of the density of material across the settlement. The first step in this strategy was to create a 1 ha grid across the site; this was done using the Universal Transverse Mercator (UTM zone 36 north) coordinate system. Collections were taken from a $10 \mathrm{~m} \times 10 \mathrm{~m}$ collection unit placed at each hectare's southwestern corner. These collection units were identified on the ground using either handheld Garmin 62s GPS devices or handheld smartphones or tablets. Data were recorded on site using the ArcGIS Collector application on surveyors' phones or tablets. After an initial 'sweep' of collection units across the höyük and its surroundings, a second pass was completed where surface artefacts were now known to be present. This time the collection units were placed in the centre of each hectare, resulting in two units being collected per hectare in these areas (fig. 4a).

On the surface of the höyük, where surface remains were extraordinarily dense, we derived two primary datasets from the collection units. The first comprises the total collection of artefacts from $2 \mathrm{~m} \times 2 \mathrm{~m}$ squares in the southwestern corner of each unit. Ceramics from these sub-units were counted and weighed as proxies for the density of the ancient settlement. The second dataset came from the remaining $96 \mathrm{~m}^{2}$ of the collection unit. From here, only diagnostic ceramic sherds - rims, handles, bases and decorated body sherds - were collected in order to explore the functional use of space. In the outer city, where surface artefacts were dramatically lighter, all remains were collected from the entire $100 \mathrm{~m}^{2}$.

Dating and type attributions of each diagnostic sherd were assigned by Fatma Şahin and Hüseyin Erpehlivan, according to comparisons with published sequences of sites in the vicinity. Field conditions for the survey varied depending on location. On the höyük, visibility was uniformly excellent, although survey units in the gullies could be a challenge due to slope and terrain. In the large pasturage that occupies most of the lower town, the vegetation cover was generally light, although areas of low grass were deceptively obscuring. More problematic in this area was the absence of active ploughing. This means that sherds and other artefacts have not routinely been brought to the surface, which itself has the consistency of hardbaked clay. Sherd visibility was thus significantly improved in the corn fields north and east of the pasturage, even though chest-high corn plants made them much more difficult to survey.

In total, 342 collection units were surveyed, including units in which no remains were found. No surveying was conducted within the modern village. Thus site-size estimates for all periods might be low; that said, from the general lack of ceramics east and west of the village, it seems unlikely that there would be Bronze and Iron Age remains in this area. From TISP's 342 collection units a total of 16,654 sherds were retrieved, of which just under 3,000 are diagnostic, along with 57 small finds. Ceramic counts were mapped to show densities across the lower town and to estimate the total size of the site. Depending on where exactly one opts to delimit the borders of the site, it appears that Türkmen-Karahöyük extended to roughly 125 ha in size, although it was not settled at this full extent in every period. 

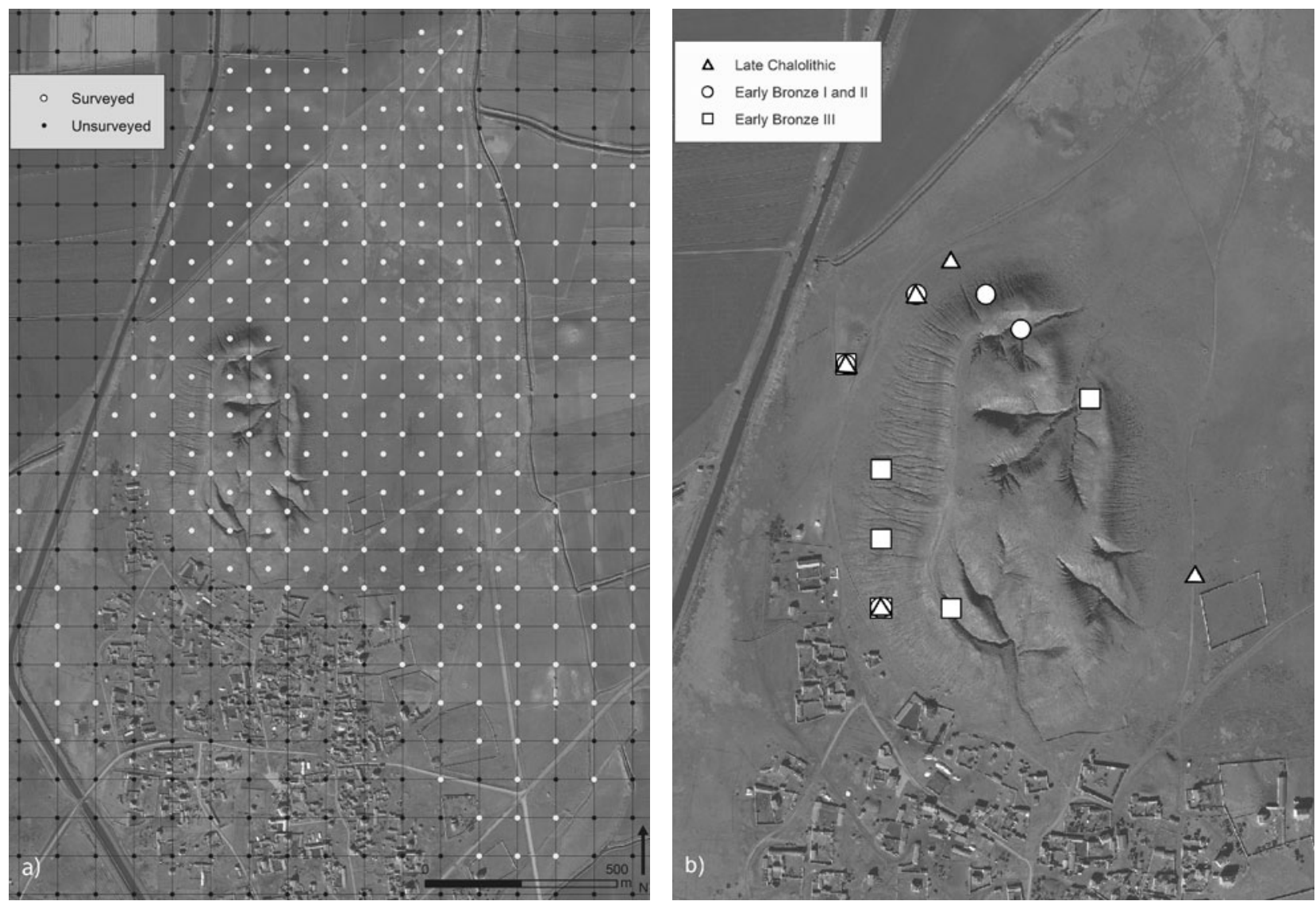

Fig. 4. (a) Survey extent of the Türkmen-Karahöyük Intensive Survey Project; (b) collection units that produced diagnostic Late Chalcolithic, Early Bronze Age I-II and Early Bronze Age III pottery.

Not surprisingly, the artefact distribution was not evenly spread across the site. The höyük produced sherds at a far greater density than the lower town, where only a very thin layer of ceramics was visible on the ground. This is likely due to a combination of factors: (1) the lower town was occupied for a briefer period of time than the upper city; (2) alluviation has buried the lower town under possibly many metres of sediment; (3) ground visibility in the lower town was mainly poor due to a lack of ploughing (and in the ploughed fields to the north sherd densities increase correspondingly); and (4) the effects of water erosion, possibly indicated by relic watercourses visible in satellite imagery to the northeast of the höyük (see fig. 3), although for now this point is speculative. That the distribution of sherds across the site is spatially meaningful, however, is indicated by the clear patterns that emerge when the collection units are mapped according to the ceramic periods they produced.

Late Chalcolithic to Early Bronze Age III (ca 4500-1950 $B C E$ )

The earliest attested occupation of Türkmen-Karahöyük is the Late Chalcolithic period, or roughly the fourth millennium BCE (fig. 4b). Late Chalcolithic and Early Bronze sherds were found on all sides of the mound, but cluster especially on its western edge. Within the mound's perimeter they are found only at the bottom of the deep gullies that cut into it from the east. These findspots are clearly related to the many metres of post-Early Bronze occupation that prevent more pottery of this time period being found on the mound's surface. Although a site-size estimate is not possible for this period, from the limited distribution available it seems likely that the fourth- to third-millennium settlement was quite large, possibly even occupying the entire area of the höyük. A fragmentary stone mace head from collection unit M18.91 is the only Early Bronze Age small find.

The small amount of Late Chalcolithic pottery collected by TISP (nine diagnostic sherds from five collection units) consists of monochrome and white-painted flaring bowls, generally with a well-fired, grey fabric (fig. 5.1). Parallels are attested at other sites surveyed on the Konya plain (Mellaart 1963: 201, fig. 4; Bahar, Koçak 2004: nos 9-11). The same parallels apply to the similarly limited quantities of ceramics from the Early Bronze I-II periods (fig. 5.2-6), including especially Red Polished Ware, Scored Ware and Plain Coarse Ware found as flaring bowls, beak-spouted jugs, cups, closed pots and jars (Mellaart 1963: 210). Early Bronze IIIA ceramics were 


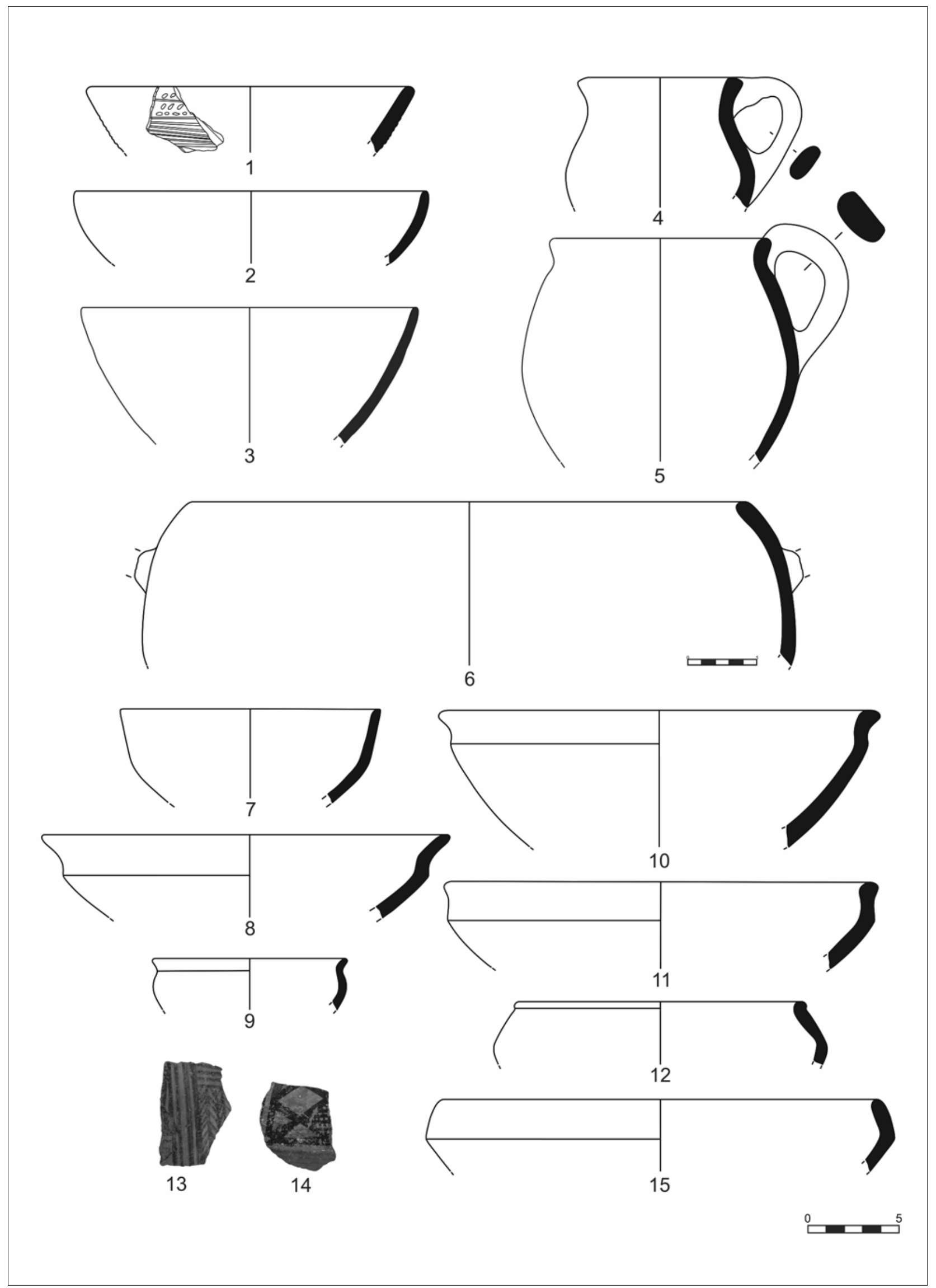

Fig. 5. Late Chalcolithic to Early Bronze Age pottery from Türkmen-Karahöyük. 1 Late Chalolithic; 2-6 Early Bronze Age I-II; 7-9 Early Bronze Age IIIA; 10-15 Early Bronze Age IIIB/Transitional Middle Bronze Age. 


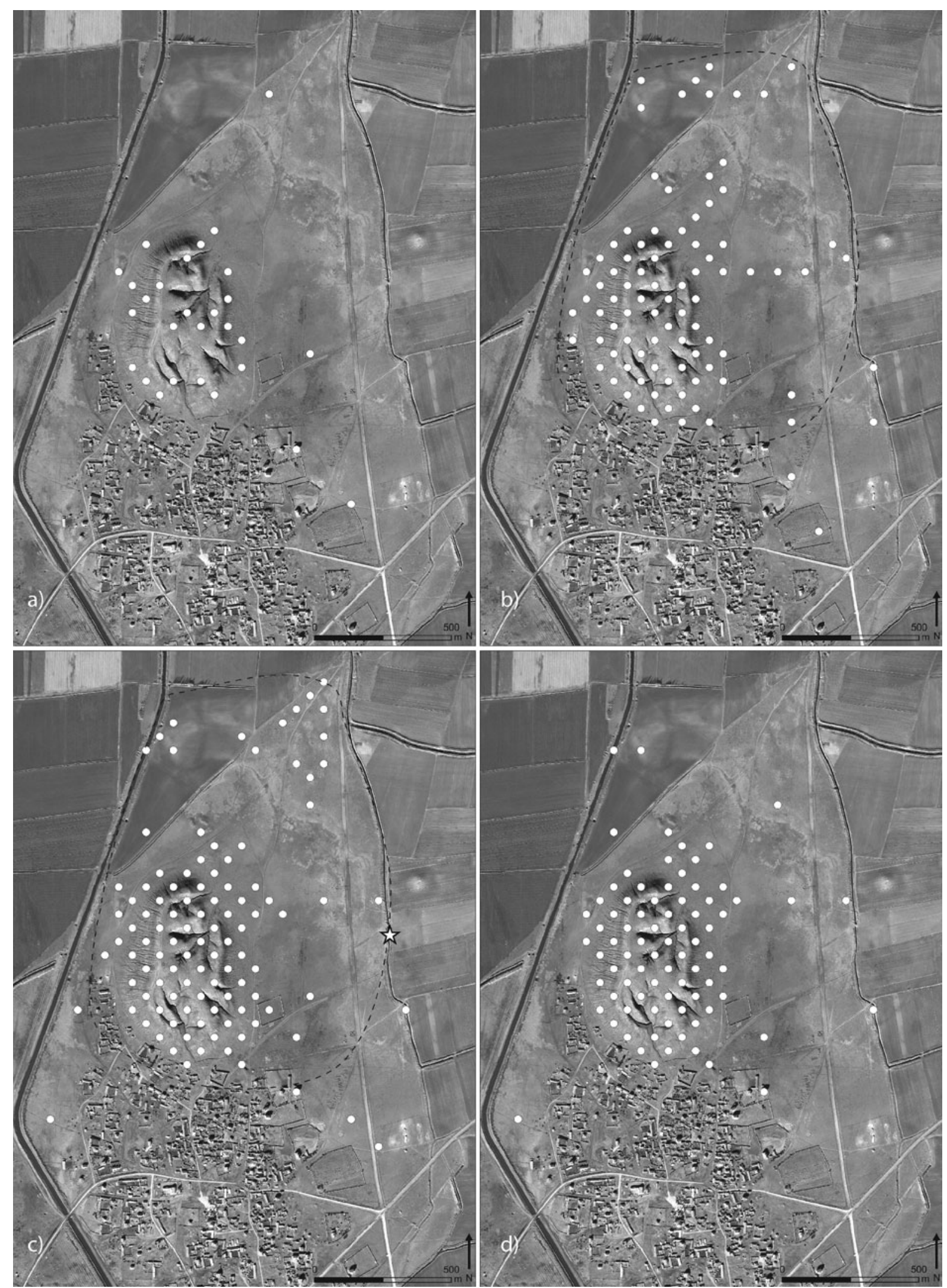

Fig. 6. (a) Collection units that produced diagnostic Middle Bronze Age pottery; (b) collection units that produced diagnostic Late Bronze Age pottery, with a dashed line indicating hypothetical city limit at ca 125ha; (c) collection units that produced diagnostic Iron Age pottery, with a dashed line indicating hypothetical city limit at ca 125 ha and a star indicating the findspot of inscription TÜRKMEN-KARAHÖYÜK 1; (d) collection units that produced diagnostic Late Iron Age pottery specifically. 
mostly recognised as western Anatolian Red Coated Ware (Blegen et al. 1950: 221), especially bowls with an 'S' profile (fig. 5.7-9). During the Early Bronze IIIB, or the transitional period into the Middle Bronze Age, 'S'-profile bowls, bulbous-rim bowls and bead-rim bowls were quite common (fig. 5.10-12), with brown-red fabrics and small stone and mica inclusions. Similar examples of such beadrim bowls in particular are attested at a number of contemporary sites including Küllüoba (Şahin 2014; 2015), Polatlı (Lloyd, Gökçe 1951), Gordion (Gunter 1991) and Boğazköy (Orthmann 1963), among others. The ware type known as Alişar III was also collected (fig. 5.13-15), and resembles most closely examples from Kültepe level 11a (Omura 1991: 151, fig. 1-8) and Alişar Höyük (von der Osten 1937: figs 237, 248, 256-57).

\section{Middle Bronze Age (ca 1950-1650 BCE)}

The Middle Bronze Age was the first period in which settlement unambiguously spread across the entirety of the höyük. Excluding four collection units spread far from one another in the lower town, the total settled area of Türkmen-Karahöyük during the early second millennium was at least 30 ha, roughly corresponding in size to the other large Middle Bronze centres of the Konya plain (fig. 6a; see Massa et al. 2020, this volume). Small finds clearly belonging to the Middle Bronze Age are rare, save for one second-millennium ceramic spindle-whorl and a ceramic crescent loomweight from unit K17.72, approximately $16 \mathrm{~cm}$ in length and with parallels at many Middle Bronze Age sites (for example Alp 1968: Taf. 144-245) (fig. 7).

There are five principal ceramic ware types belonging to the Middle Bronze Age - Red Slipped Ware, Brown Ware, Cream Ware, Grey Ware and Plain Ware - all of which continued into the Late Bronze Age. All of these have well-tempered clay with small limestone and other stone inclusions such as mica. The most diagnostic Middle Bronze ceramics include bowls (fig. 8.1-8), large bowls (fig. 8.9-14), restricted-neck jars (fig. 9.1), cooking pots (fig. 9.2-3), jars (fig. 9.4-6), pithoi (fig. 9.7), pottery painted in common Middle Bronze patterns (fig. 9.8-9) and pedestalled dishes (fig. 9.10). Bowls are commonly burnished to a shiny red polish. Hemispherical bead-rim bowls and large bowls with or without handles are particularly frequent. Ceramic parallels for Türkmen-Karahöyük's Middle Bronze level are found at major centres across central and western Anatolia. For example, close parallels for the large bowls, restricted-neck jars and pedestal dishes are attested at Kültepe (Özgüç 1950: figs 193-94, 518, pl. XLIII), Ovaören (Aydın 2015: fig. 25) and Boğazköy (Fischer 1963: Taf. 40.44, 110, 968-69). Likewise, painted pieces belonging to the Colony period, which are painted with dark-brown or red paint on a cream or buff surface (fig. 9.8-10), also have close parallels at Kültepe (Özgüç 1950: fig. 345), Ovaören (Aydın 2015: fig. 60.3-4) and Boğazköy (Fischer 1963: Taf. 3.40-45). Related parallels to Colony period ceramics have been identified by the Konya Ereğli Survey Project (Maner 2019: 86, 89, figs 9-10).

Connections with major Colony period centres are also indicated by a body sherd found on the höyük in unit K17.34. This sherd is covered in red slip with streaky hand burnishing and has two stamp impressions on it. The pattern on the stamp used to make the impression is unfortunately very difficult to discern, but photographs in raking light and Reflectance Transformation Imaging indicate a possible rosette surrounded by two concentric circles (fig. 10). In terms of spatial organisation, it resembles closely the many stamps published from Kültepe-Kaneš Ib (Özgüç 1968: pls XXXII-XXXIX), Acemhöyük (Özgüç 2015: figs 129-33) and Konya-Karahöyük (Alp 1968: Taf. 193 96). In addition to the cultural connections this piece raises, the Kültepe-Kaneš $\mathrm{Ib}$ parallel is also helpful chronologically, dating the sherd to the late 19th to 18th century (Oya Topcuoğlu, personal communication).

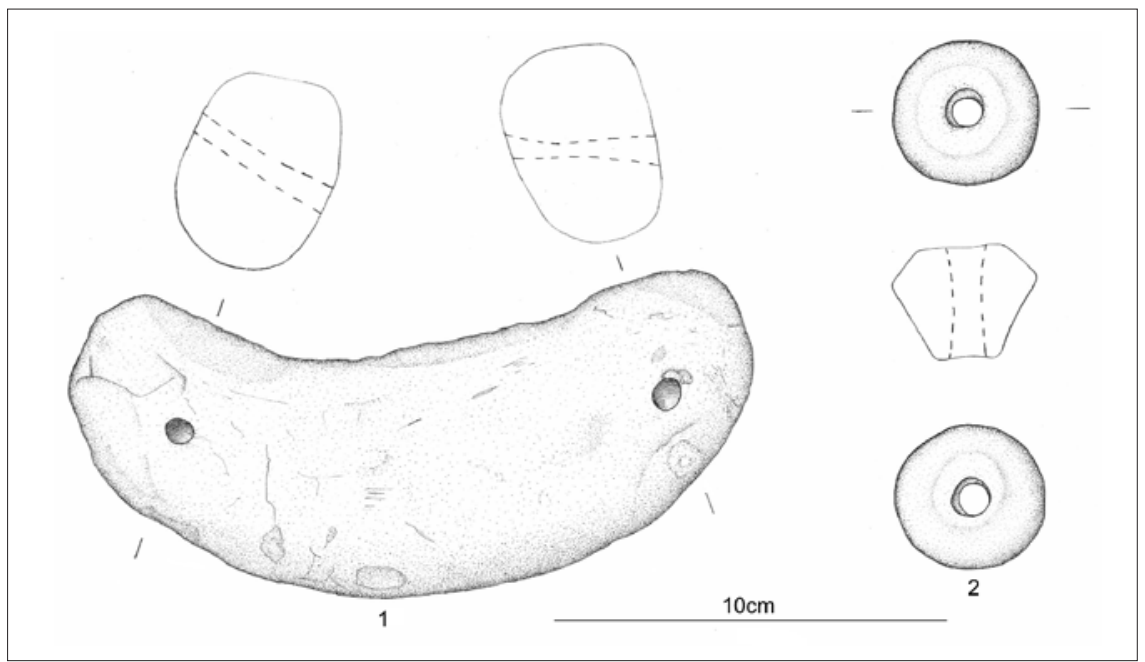

Fig. 7. Second-millennium objects. 1 ceramic crescent loomweight, Middle Bronze Age; 2 stone spindlewhorl, Middle to Late Bronze Age. 


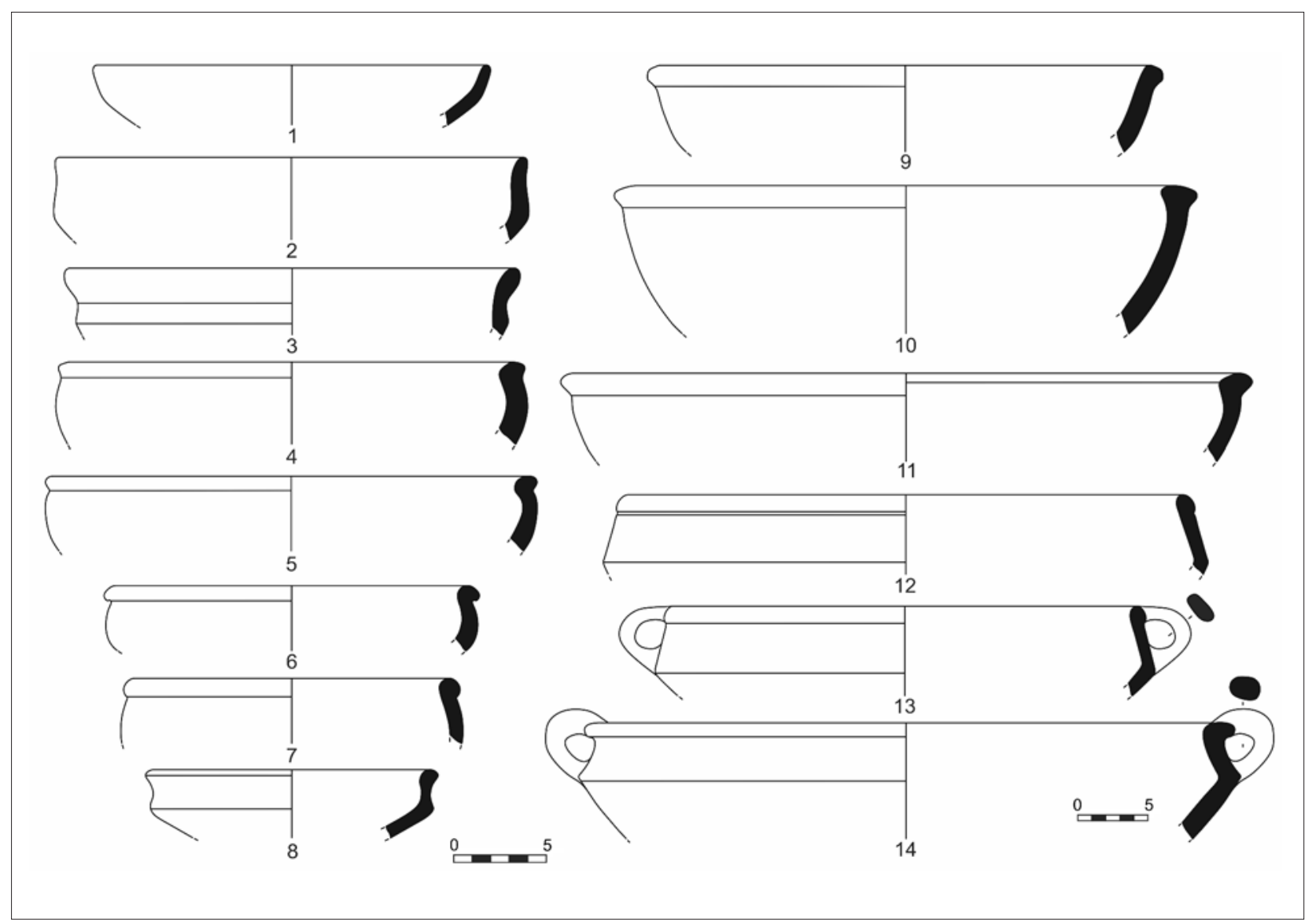

Fig. 8. Middle Bronze Age bowls from Türkmen-Karahöyük.

Late Bronze Age (ca 1650-1200 BCE)

During the Late Bronze Age, settlement expansion beyond the höyük took place in a dramatic fashion (fig. 6b). However, the relative scarcity of pottery in the lower town, due to the reasons described above, makes an estimate of the site's size at this time difficult to produce. Collection units over $700 \mathrm{~m}$ north and northeast of the höyük produced Late Bronze Age sherds, as did a row of units several hundred metres east in the direction of the tumulus. These clearly must be considered as within the settlement's boundary, even though large areas of open space lie between them. Several units southeast of the höyük likewise produced Late Bronze Age pottery, but do not cluster spatially. They cannot be entirely discounted, however; if they were simply the result of wash or erosion from the höyük, one would expect to see sherds of all periods in these outer fields, yet this is not the case for any period other than the Late Bronze and Iron Ages, including in the field north of the pasture that was actively ploughed. This area southeast of the höyük lies beyond the second 'sweep' of collection units; thus this area was surveyed half as thoroughly as the lower town north and northeast of the höyük. A conservative estimate for the area of the Late Bronze city is therefore in the order of $125 \mathrm{ha}$ (see fig. 6b).
The inclusion of all the relevant collection units produces a settlement of at least $150 \mathrm{ha}$ - and this still excludes the entirety of the area of the modern village. The conservative estimate is supported by the general sparseness of ceramics in the east and southeast; the more generous estimate is supported by the fact that Iron Age pottery was likewise found in isolated units in this same part of the pasturage, implying that the general sparseness is simply a result of taphonomic processes, especially alluviation. In either instance, Türkmen-Karahöyük roughly quadrupled its Middle Bronze Age extent during the Late Bronze Age, becoming one of the largest Bronze Age sites in Anatolia.

Late Bronze Age ceramics continue the Middle Bronze traditions, with the notable exceptions of the decreased use of mica as a tempering agent and the first appearance of the so-called Drab Ware of the Hittite Empire period (Schoop 2011: 242), or what Claudia Glatz would label 'north-central Anatolian-style' pottery (2009: 129-30). Indeed, the overwhelming characteristic of Late Bronze Age pottery at Türkmen-Karahöyük is its resemblance to the ceramic traditions of the central Anatolian plateau. Bowls (fig. 11.1-5), flat bowls (fig. 11.6-12) and large, deep bowls (fig. 11.15-17) are the most commonly attested Late Bronze Age forms and appear in Red Slip Ware, Drab 


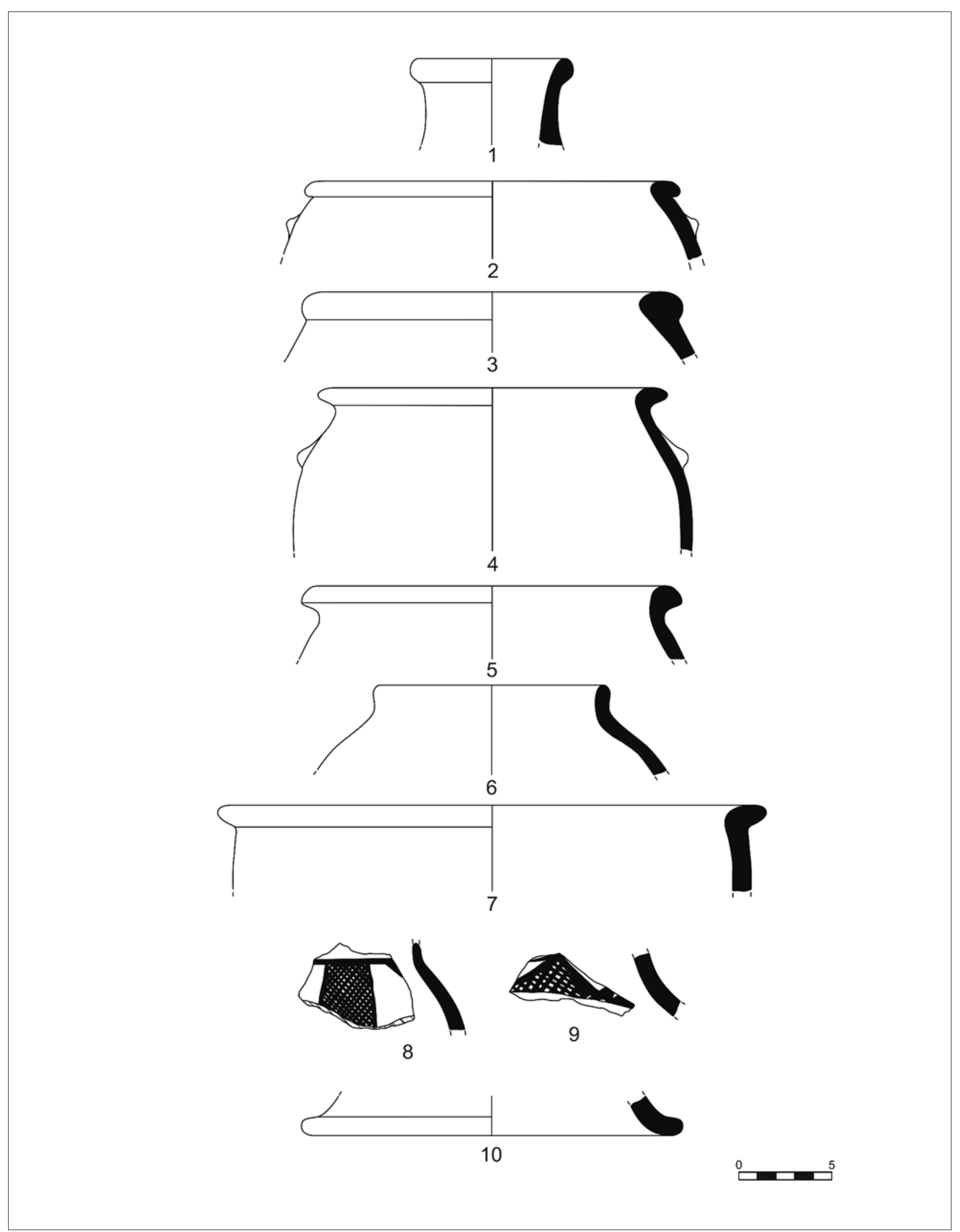

Fig. 9. Middle Bronze Age jars, cooking pots and pithoi from Türkmen-Karahöyük. 


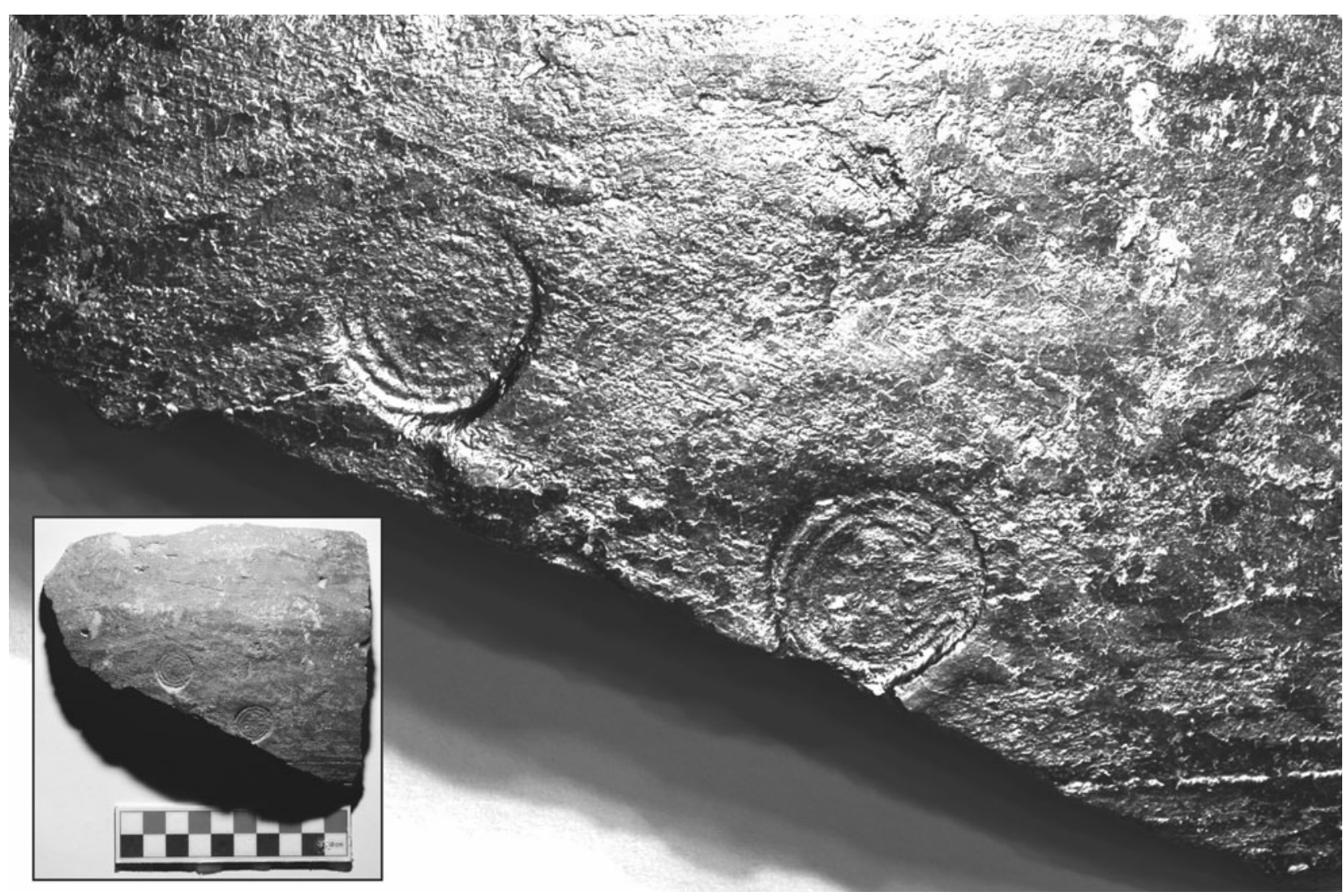

Fig. 10. Stamped sherd from the late 19th to 18th century BC (snapshot taken from Reflectance Transformation Imaging; photograph and RTI by Jennifer Jackson).

Ware and Plain Ware. Flat bowls occur in small $(10-12 \mathrm{~cm}$ diameter) and large (30-60 $\mathrm{cm}$ diameter) varieties. The best examples of such vessels occur in Hittite centres such as Boğazköy (Fischer 1963; Parzinger, Sanz 1992) and Kuşaklı (Arnhold 2009).

Such ceramic connections with major Hittite sites may have significant implications for how to interpret Türkmen-Karahöyük during the Late Bronze Age. Similar indications are offered by the presence of more elite vessels such as 'Eggshell Ware' bowls (fig. 12.1-2) (Schoop 2011: 245) and other fine bowls (fig. 12.3-4), which have close parallels with examples from Boğazköy (Fischer 1963: Taf. 83.698-702, 98.887, 899). Parallels to the rare votive vessels recovered from sacred ponds and temples at Boğazköy appear in Türkmen-Karahöyük's Late Bronze Age corpus (for example fig. 12.5-6; cf. Fischer 1963: Taf. 119.1040, 1062). Container vessels for liquids, such as jugs (fig. 12.8) and restricted-neck jars (fig. 12.9-10), which appear in Cream Ware or Plain Ware, are considered typical of Hittite households (Schoop 2011: 253) and have parallels from Boğazköy (Fischer 1963: Taf. 40.444, 43.441) and Kuşaklı (Arnhold 2009: Taf. 2). Storage vessels, such as jars and pithoi, were also frequently collected at Türkmen-Karahöyük (fig. 12.1115 ), with parallels from the same sites on the plateau.

\section{Iron Age (ca 1200-300 BCE)}

Iron Age occupation at Türkmen-Karahöyük remained at the extremely large extent seen during the preceding Late Bronze Age (fig. 6c). The collection units that produced diagnostic pottery from this era are generally within the same clusters in the lower town as those that produced evidence of occupation during the previous period. This implies that these clusters are spatially significant, but unfortunately leaves us again with ambiguity regarding the site's size. As before, the Iron Age city must have been somewhere between $125 \mathrm{ha}$ and $150 \mathrm{ha}$ in size, assuming there was no settlement beneath the modern village and that ceramic gaps in the outer town are due to taphonomic processes.

Following the central Anatolian Iron Age dating system adopted for Kaman Kalehöyük (Matsumura 2005: 87-96, 431-501), the difference between the Early (ca 1200-900 BCE) and Middle Iron Age (ca 900-600 BCE) pottery in this region is almost impossible to discern. Pieces that can only belong to the Late Iron Age (ca 600-300 BC) are more clearly identifiable, however, and, when collection units that produced ceramics restricted to the Late Iron Age are mapped, it is apparent that settlement at TürkmenKarahöyük retracted to roughly 50ha (fig. 6d). It follows, therefore, that the Late Iron Age witnessed the start of 

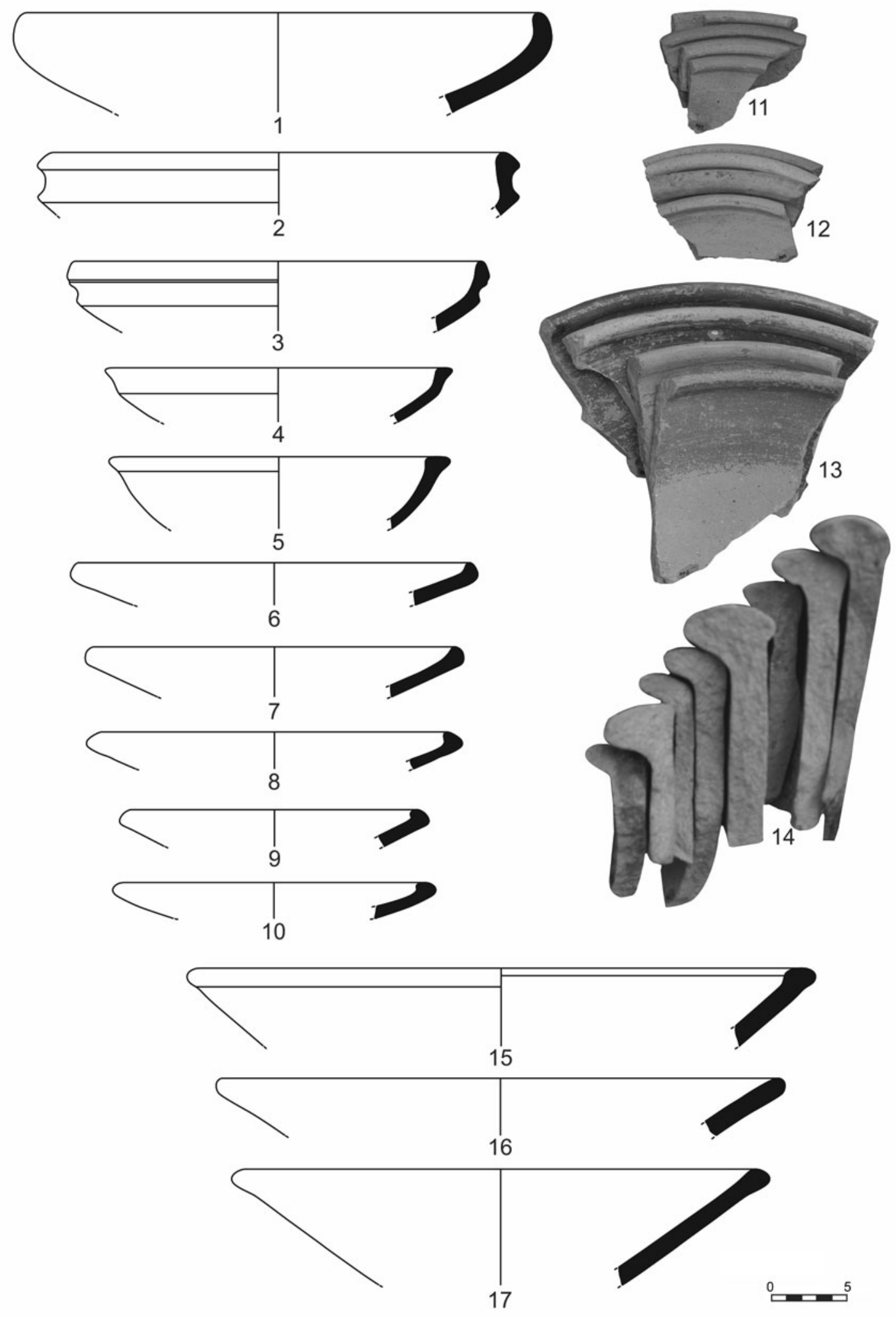

Fig. 11. Late Bronze Age bowls and plates from Türkmen-Karahöyük. 


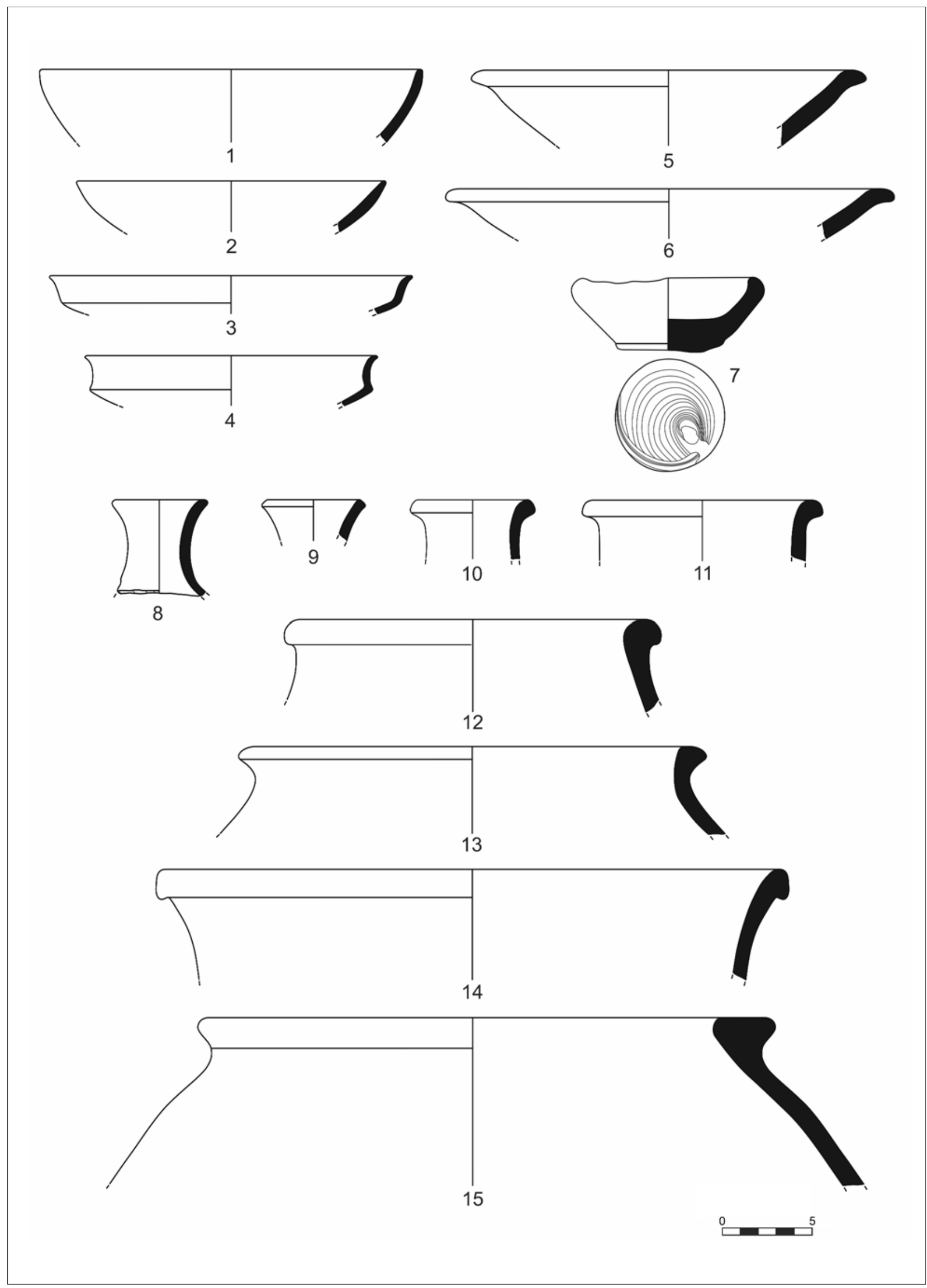

Fig. 12. Late Bronze Age Eggshell Ware (1-2), fine bowls (3-4), votive vessels (5-7), jugs and storage jars (8-13), and pithoi (14-15) from Türkmen-Karahöyük. 
Türkmen-Karahöyük's gradual decline and that its maximum extent lasted from the Late Bronze Age until the Middle Iron Age. Contraction back onto the höyük continued during the subsequent Hellenistic period. This era lies beyond the permit terms related to the project's periods of study and thus will not be described further here. A $3.5 \mathrm{~m}$-wide mudbrick fortification wall visible in profile near the surface of the site around the eastern summit of the mound must also date to the Late Iron Age or later and shows signs of having been burned in a massive city-wide destruction.

The Iron Age pottery found at Türkmen-Karahöyük by TISP can be classified into five primary traditions, all of which are in the preliminary stages of analysis. They are predominantly wheel made: Common Ware, so-called Alişar IV Ware, Black-on-Red Ware, so-called Phrygian Grey Ware and possible Cilician imports. Of these groups, the most frequent is Common Ware, particularly for the Late Iron Age. The fabric of this ware consists of cream or buff coloured clay, sometimes with an additional selfslip. An Early Iron Age tradition of black- or brownpainted pottery (figs 13.17, 14.5, 15.30) is the likely ancestor of the Middle Iron Age so-called Alişar IV Ware at Türkmen-Karahöyük (fig. 14.14-15, 18-19). Examples of the latter are of an exceptionally high quality, with finely painted designs on thoroughly burnished surfaces. Additional study is required in order to evaluate whether Türkmen-Karahöyük itself may have been a production centre of this ceramic tradition on the Konya plain (cf. Summers 2009: 660-61). A handful of Black-on-Red Ware sherds, consisting of black-painted bands on red clay and possibly locally produced, are evident at TürkmenKarahöyük, especially for the Middle Iron Age (fig. 13.9). So-called Phrygian Grey Ware (figs 13.3, 12, 21, 14.6-7, $12,15.1,7)$ is present in low numbers for the Middle Iron Age.

Thus the Konya plain's largest Iron Age site has yielded both Alişar IV and Grey Ware in survey, meaning that Türkmen-Karahöyük appears to serve as a confluence of the ceramic traditions that, rightly or wrongly, have been associated with both the Syro-Anatolian kingdoms in Cappadocia and related sites north of the Kizllirmak, on the one hand, and Phrygia, on the other (cf. Mellaart 1955: 116; Kealhofer et al. 2015). Indeed, a similar overlap of these two traditions is also attested at sites within the bend of the Kizilirmak. The assemblage of the Late Iron Age occupation above the Hittite granary on the northwestern slope at Boğazköy, for example, contains up to $10 \%$ Grey Ware (Genz 2006; 2007: 142), while excavations in Büyükkaya dating to the Middle Iron Age, or Büyükkale II in the Boğazköy sequence, have produced Alişar IV pottery decorated in silhouette style (Genz 2004: 34). The cultural significance of Türkmen-Karahöyük producing or acquiring ceramics of both traditions, albeit in small quantities, is yet to be determined (Summers 1994). For now, it can simply be noted that $1.7 \%$ of the diagnostic sherds $(n=53)$ are Grey Ware, while $4.5 \%$ of the diagnostic sherds $(n=137)$ are either Alişar IV Ware proper or, much more commonly, its antecedent, simple pottery painted with brown or black bands. For the Late Iron Age, Common Ware dominates the collection following the disappearance of Alişar IV. A small collection of bowls characterised by red or black painted bands and imported from Cilicia is an important subgroup (fig. 13.11, 13-15, 22), alongside local imitations (fig. 13.24).

Morphologically, the Iron Age assemblage of Türkmen-Karahöyük is characterised by plates, bowls, cups, kraters, jugs, jars and pithoi. All of these appear in Common Ware, for which the closest parallels in terms of both form and fabric derive from Kınık Höyük (Ergürer 2016), especially for the Late Iron Age. A number of ceramic similarities are attested at Gordion, such as plates and bowls appearing in both Early Phrygian (Sams 1994: figs 6.33, 8.89, 18.487, 18.286, 53.335) and Persian levels (Toteva 2007: cat. 10). As expected, examples of Türkmen-Karahöyük Grey Ware bear a number of similarities to specimens from Gordion, including kraters (Sams 1994: fig. 53.335) and jugs (Sams 1994: fig. 40.915), although this is harder to determine for Gordion's less-published Late Iron Age ceramics. Türkmen-Karahöyük's painted Middle Iron Age vessels (fig. 14.18-19) are also paralleled in Early Phrygian Gordion (Sams 1994: pls 112.185, 51.607, 55.1038, 97.832), as well as Alişar itself(von der Osten 1937: pl. X, cat. B.2542); a decorated body sherd of a jar (fig. 15.13) is identical to a Middle Iron Age example from Boğazköy-Büyükkaya (Genz 2000: Abb. 7.1).

Several preliminary statements can be made as hypotheses on which future research on Türkmen-Karahöyük's Iron Age pottery might be based. First, the Iron Age ceramics from Türkmen-Karahöyük show a great deal of continuity from the Early Iron Age down through the Late Iron Age and beyond. Second, as elsewhere in Anatolia, the Early Iron Age remains the least well understood era. Third, the Alişar IV ceramics at the site are at least as finely made as anywhere else in Anatolia. As suggested above, a future research avenue will be to explore whether the Konya plain, and TürkmenKarahöyük specifically, may have been a possible locus of production. Fourth, the presence of Grey Ware similarly requires exploration in terms of commercial and cultural relations between Tabal and Phrygia. For now, the ceramic evidence indicates that Türkmen-Karahöyük may have served as a cultural intermediary between these two traditions. Fifth, by the Middle Iron Age there is strong evidence for ceramic connections with Cilicia and 


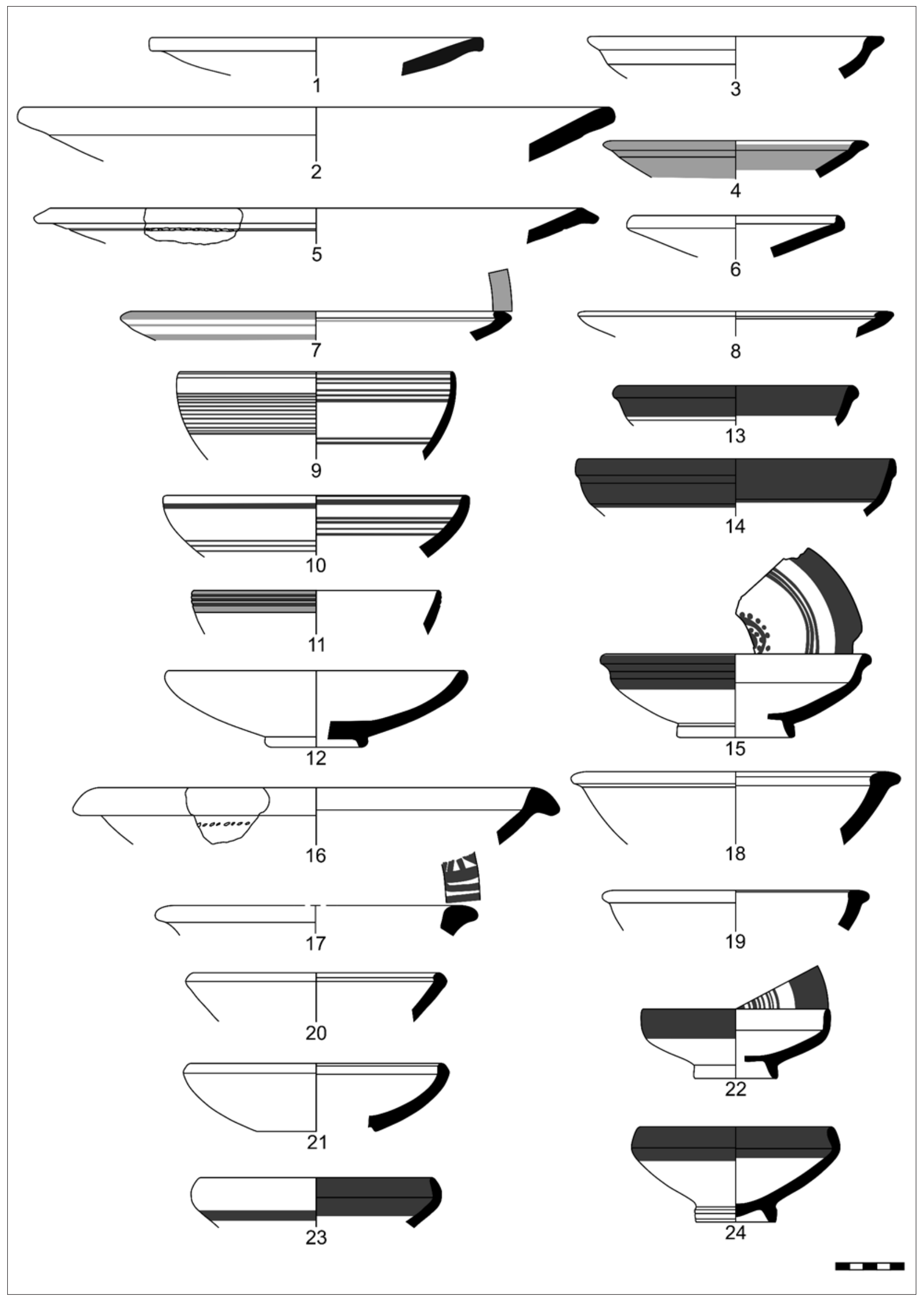

Fig. 13. Iron Age bowls and plates from Türkmen-Karahöyük. 


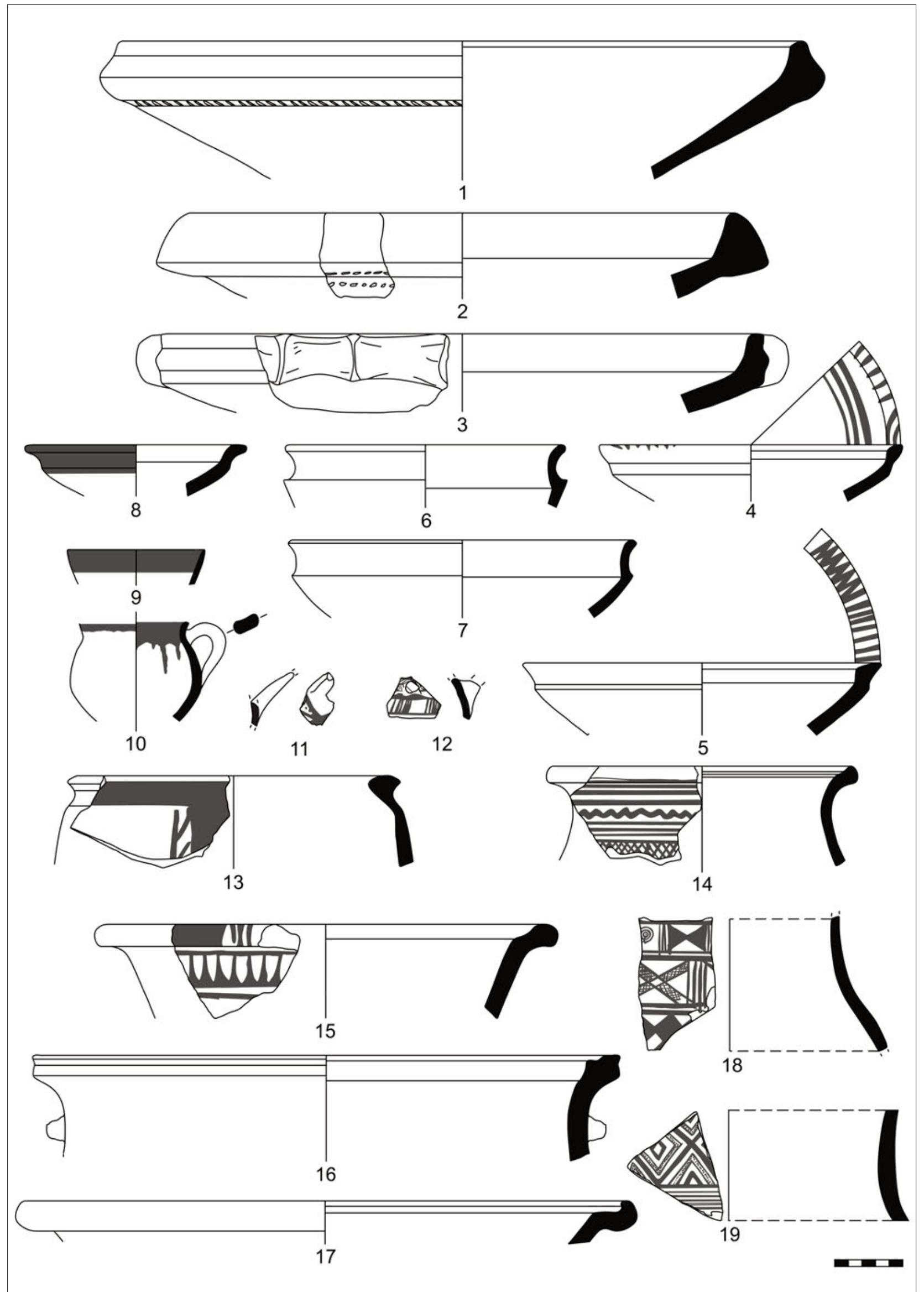

Fig. 14. Iron Age bowls, cups and kraters from Türkmen-Karahöyük. 


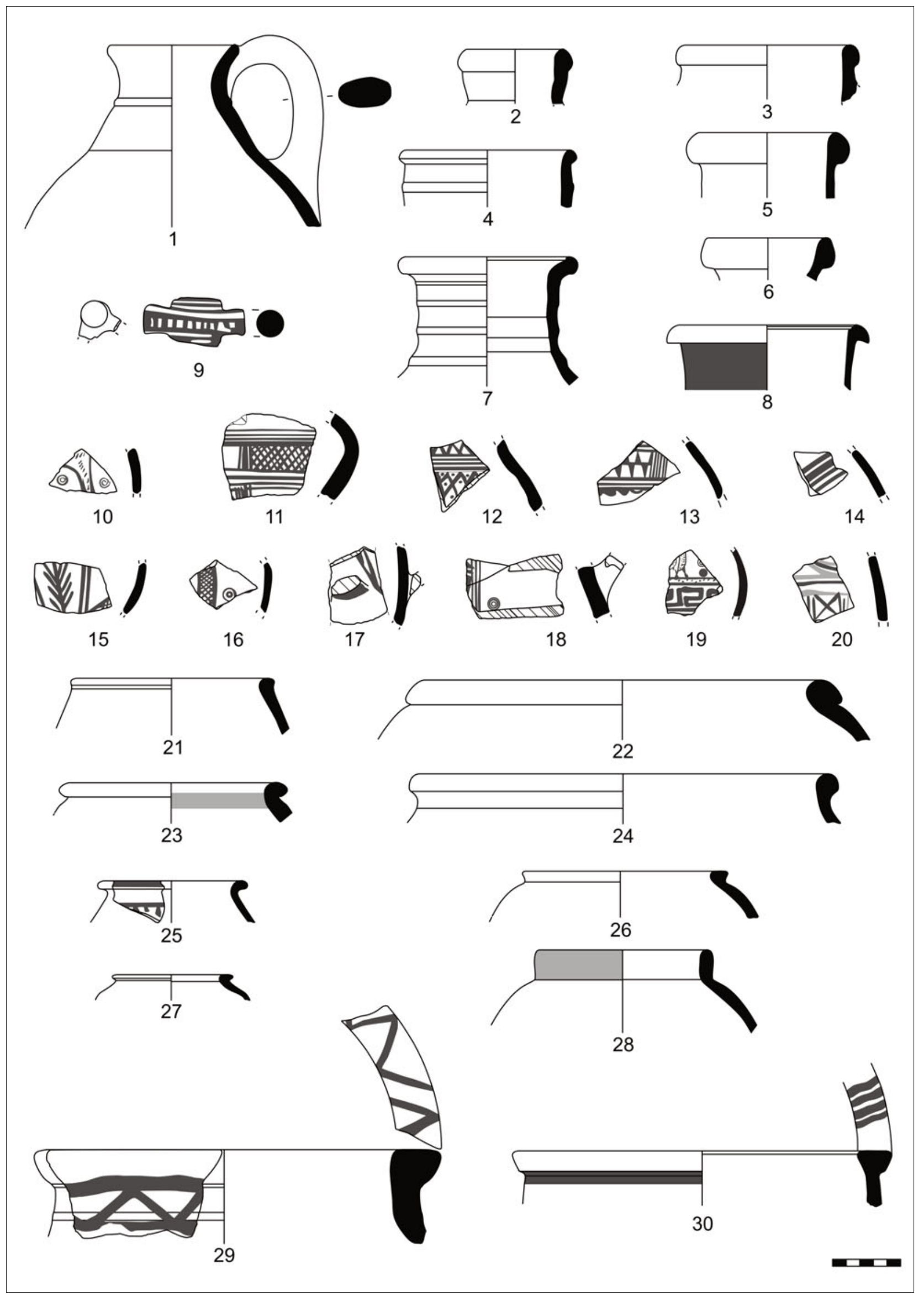

Fig. 15. Iron Age amphorae, jugs and jars from Türkmen-Karahöyük. 
Cyprus. By the same token, the lack of Greek imports in the Late Iron Age is perhaps indicative of TürkmenKarahöyük's decline at this time, or at least its insularity. The impact of geopolitical circumstances on ceramic developments in this part of Anatolia during the sixth century BC, especially the retreat of the Lydian kingdom and the ensuing Persian domination, is another topic to be explored in future research.

\section{The Hieroglyphic Luwian Inscription: TÜRKMEN- KARAHÖYÜK 1}

The most dramatic individual discovery made by TISP is a stele inscribed in Hieroglyphic Luwian, a discovery that took place on 25 June 2019. Following the labelling conventions of Hawkins (2000), we refer to this inscription as TÜRKMEN-KARAHÖYÜK 1. While we were surveying in the fields just beyond the far eastern edge of Türkmen-Karahöyük's lower town, a local farmer informed us of an inscribed block he had found nearby while dredging the modern irrigation canal that runs northsouth along the eastern side of the lower town (fig. 16). Shallow scratches on the stone's surface are possibly from this activity. Subsequent conversations with villagers in recent months have queried this discovery narrative, however, with some locating its findspot on the mound itself. Ultimately, it is unclear where exactly on the site the stele was originally found. Discolouration on the bottom of its face (i.e. the third line and the bottom left of the second line) perhaps derives from the lower part of the stone being buried in the muddy bottom of the canal while the top was exposed to water.

Although no tests have been performed to obtain a secure identification, the stone itself is likely a siltstone or mudstone; that is, it is comprised of fine-grained terrigenous sediments (Susan Kidwell and Jacob Waldbauer, personal communication). This type of stone is commonly found in the far reaches of alluvial outwash. The stele measures approximately $95 \mathrm{~cm} \times 45 \mathrm{~cm}$; precise dimensions are not easily expressed since the boulder is not fully worked. While the top and right sides appear to have been worked roughly to a level, the left side was left unfinished and its rounded edges indicate that it had this form in antiquity. The bottom edge has a sharper break, indicating more recent damage, and, indeed, this is where the only incomplete sign is attested. Reflectance Transformation Imaging has permitted us to make the inscription available to philologists who have not seen the stone in person and to view its text under a myriad of different light sources (fig. 17). The stele consists of a three-line inscription composed by 'Great King K/Hartapu', written in both relief (Kartapu) and incised text (Hartapu), and narrates his defeat of the Muška, commonly understood to refer to Phrygia, as well as 13 additional kings. Palaeographic

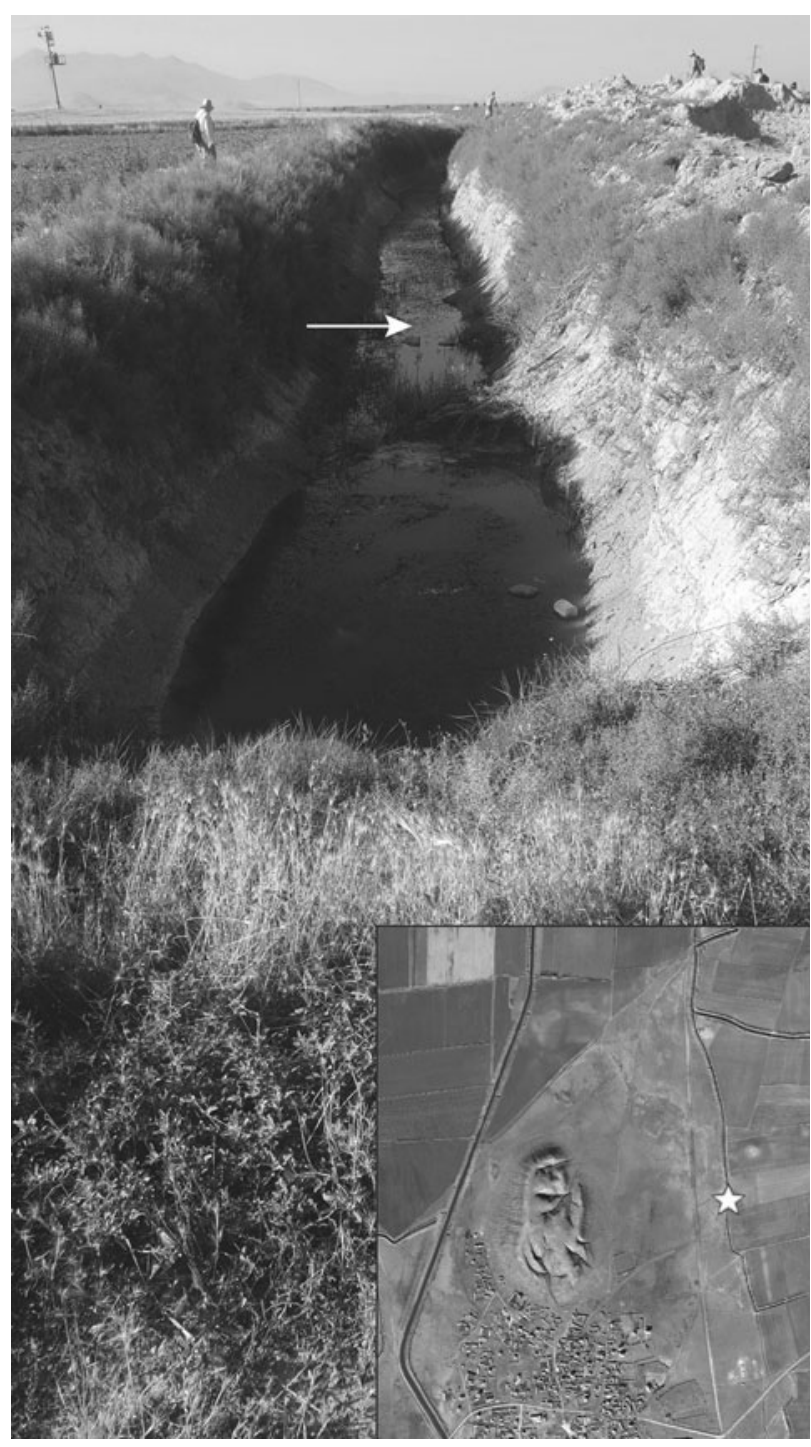

Fig. 16. Findspot of the TÜRKMEN-KARAHÖYÜK 1 inscription in an irrigation canal running north-south along the eastern edge of the lower town, facing south (photograph by James Osborne).

parallels with other Iron Age Hieroglyphic inscriptions, especially those from Tabal, suggest an eighth-century date for the text (for a translation and commentary, see Goedegebuure et al. 2020, this volume).

Besides the historical importance of the geopolitical information contained in TÜRKMEN-KARAHÖYÜK 1 - otherwise unattested conflicts between Hartapu and Phrygia, and between Hartapu and 13 local kings (see 'Discussion and conclusion', below) - this inscription has profound implications for how we understand the site of Türkmen-Karahöyük as an urban centre. First and foremost, it indicates that the site was almost certainly Hartapu's royal residence, that is, a capital city within the region of Tabal, during the eighth century, and therefore likely before that time as well. Such was already implied by the site's size, and now that fact is accompanied by a 
royal inscription authored by a 'Great King'. The ancient name of Hartapu's capital remains unknown. Second, although we cannot be certain about the stele's original context, its presence either within the höyük or on the edge of the settlement points toward the existence of monumental architecture accompanied by sculpted stone orthostats and statuary in the manner of other SyroAnatolian cities such as Carchemish and Malatya.

\section{Discussion and conclusion}

Considered in aggregate, the results produced by TISP during its first season of fieldwork are quite remarkable. For each of the cultural horizons attested at the site, Türkmen-Karahöyük is now a major contributor to the scholarly narratives that dominate those periods. The site was occupied from the Late Chalcolithic period and was likely quite a substantial settlement even at that time and
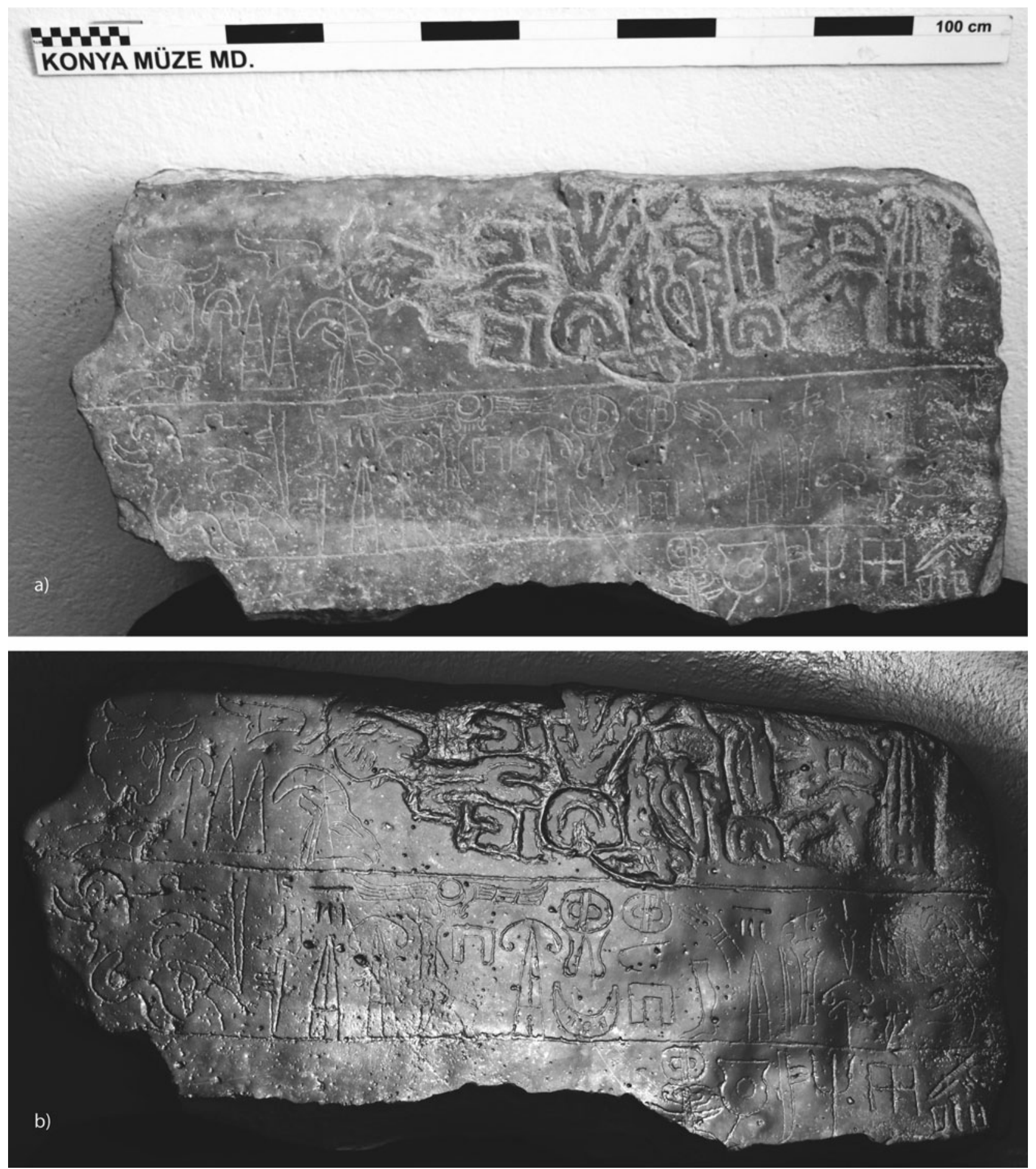

Fig. 17. Photographs of the inscription TÜRKMEN-KARAHÖYÜK 1 in regular light (a) and Reflectance Transformation Imaging (b) (photographs by Jennifer Jackson). 
through the Early Bronze Age, when Anatolia underwent major transformations toward social complexity. By the Middle Bronze Age, it was a 30ha town, and ceramics and small finds gesture towards its involvement in the Old Assyrian Trade Colony network of exchange that stretched from the Sakarya river to northern Mesopotamia. In the Late Bronze Age, Türkmen-Karahöyük expanded to at least $125 \mathrm{ha}$, at which time it must have been one of the most important cities in the Lower Land, especially if Massa and colleagues' identification of TürkmenKarahöyük as the elusive Hittite capital city of Tarhuntašša is correct (Massa et al. 2020, this volume); such an identification is supported by the overwhelmingly 'Hittite' appearance of the ceramics collected by TISP and the site's demonstrated political significance in the subsequent Iron Age. Either way, it seems certain that Türkmen-Karahöyük must have been a southern Anatolian counterweight to the major centres of north-central Anatolia during the Late Bronze Age.

Most dramatically, TISP has proven TürkmenKarahöyük to be a previously unknown Iron Age capital city in Anatolia, with no readily apparent break in its trajectory from its Late Bronze significance. Tabal has long frustrated scholars due to a lack of even basic historical or archaeological information about its political history and political geography, let alone social organisation. TÜRKMEN-KARAHÖYÜK 1's reference to '13 kings' defeated by Hartapu is therefore a vivid affirmation of the picture of multiple small kingdoms with highly malleable borders (cf. Osborne 2013) and shifting political allegiances that is presented by Neo-Assyrian inscriptions, such as Shalmaneser III's reference to 24 kings, and Hieroglyphic Luwian inscriptions from Tabal, such as the 11 kings mentioned in TOPADA (Şenyürt, Akçay 2018). The results of TISP allow us to place one of these kingdoms' capital cities securely on the map at Türkmen-Karahöyük. Furthermore, this city was not a conventional small höyük repurposed to meet the exigencies of a new, fleeting political formation. Rather, Türkmen-Karahöyük was one of the largest cities of Anatolia at the time, and had been for several centuries. However, it needs to be emphasised that our current understanding of Türkmen-Karahöyük's size is hypothetical and requires confirmation through further research. Continued survey and especially geophysical prospection will be necessary to gain clarification on this point. If the current understanding is accurate, then compared with its Middle Iron Age contemporaries in the Syro-Anatolian Culture Complex to the east, even the conservative size estimate of Türkmen-Karahöyük at 125ha renders it the largest of its peers, most of which range from 35 ha to 50 ha or less (Arslantepe, Tell Ahmar, Tell Halaf, Tell Tayinat, Zincirli) and only two of which Carchemish (90ha) and Tell Rifa'at (105ha) - even approach it in terms of scale. To the north, no Iron Age site in central Anatolia is this large until the foundation of Kerkenes Dağ in the late seventh century BC. At 'slightly more than 100 ha' (Rose 2017: 137), even Gordion, capital city of Phrygia, was apparently smaller than the city of Hartapu. Regardless of the extent of Türkmen-Karahöyük's lower settlement, the estimation of which may be modified following future fieldwork, it is noteworthy that, at roughly 30 ha or slightly less, the upper mound of TürkmenKarahöyük is approximately twice as large as Gordion's citadel mound (13.5ha: Rose 2017: 137).

The comparison with Gordion is particularly significant given its contemporaneity with Hartapu and the conflict described between them in TÜRKMENKARAHÖYÜK 1. Assuming the palaeography's eighthcentury attribution is correct - and this is supported indirectly by the mention of Muška in the text, which appears most frequently during the reign of Sargon II then Hartapu likely reigned either around the same time that Tumulus MM was built, ca 740 BC (Rose, Darbyshire 2011: 2), or during the lifetime of Phrygia's late eighthcentury King Mita, attested in the texts of Sargon II. Considering TISP's results in light of the Neo-Assyrian texts from this period that pair Tabal and Muška as apparent equals (d'Alfonso 2012: 175-81), we see that Türkmen-Karahöyük and its ruler Hartapu made a dramatic entry onto the central Anatolian stage as major geopolitical actors of the early first millennium. The conditions for this to occur could not have emerged overnight, and indeed we know that they did not: TürkmenKarahöyük must have been one of the major political centres of southern Anatolia, if not the centre, since the Late Bronze Age. It is therefore not unlikely that the Tabalian kingdom based at Türkmen-Karahöyük had rivalries with Phrygia in the decades prior to the reign of Hartapu, leading one to speculate whether this kingdom can be offered as a plausible candidate for the agent responsible for the destruction of Early Phrygian Gordion around $800 \mathrm{BCE}$ - assuming one accepts a military agent at all, which the Gordion excavators now doubt (for example Rose 2012: 6-7). The same view of a major ninthto eighth-century geopolitical rivalry between Phrygia and a powerful kingdom in Tabal was arrived at by the Gordion team following their redating of the destruction of the Early Phrygian citadel (Sams, Voigt 2011: 155-56); it follows from this paper that that powerful kingdom in Tabal was based at Türkmen-Karahöyük.

Our sudden awareness of Türkmen-Karahöyük as the 'city of Hartapu' also leads immediately to an improved understanding of the Kizıldağ complex and the related inscriptions at Karadağ. As proposed elsewhere (Osborne forthcoming), even before the discovery of TÜRKMENKARAHÖYÜK 1 it was plausible that the relief of a seated 
king beside the Hieroglyphic Luwian cartouche of 'Great King Hartapu' in KIZILDAĞ 1 was created as a single unit in the ninth or eighth century, despite the ostensibly earlier nature of the script. This reconstruction - pace the many scholars who have proposed that the text of KIZILDAĞ 1 must predate the relief by several centuries (following Hawkins 1992) - now seems certain. Considering the throne monument of Kızıldağ in relation to TürkmenKarahöyük, their proximity to one another - just $14 \mathrm{~km}$ apart - is quite striking, and, in fact, the two are intervisible. Kızıldağ is clearly identifiable even from ground level at Türkmen-Karahöyük and, standing on the 'throne monument' at Kızıldağ, Türkmen-Karahöyük is plainly visible to the north (fig. 18). It is easy to envision Hartapu and other rulers of Türkmen-Karahöyük leading a retinue to Kızıldağ and performing rites on the throne monument before the crowd gathered below and then continuing south to the slopes of Karadağ. As proposed by Petra Goedegebuure and colleagues (2020, this volume), the dating of the entire Kızıldağ-Karadağ complex will now have to be reconsidered; it possibly belongs to the eighth century, given its texts' numerous parallels with TÜRKMEN-KARAHÖYÜK 1. Furthermore, the cumulative function of these inscriptions and their associated monuments requires a thorough re-evaluation in light of their association with the nearby city of TürkmenKarahöyük.

The Türkmen-Karahöyük Intensive Survey Project has several tasks remaining. First, we need to complete additional collection units of surface artefacts from the lower town, and in the southeastern quadrant especially. With additional surface data it might be possible to evaluate, for example, spatially significant patterns in ceramic functions, such as storage vessels clustering in particular neighbourhoods (for example Osborne and Karacic 2017: figs 12-14). More pressing, however, is the need to characterise the city below the modern surface of the plain, which can only be done by means of a geophysical survey. Large-scale magnetometry, for example, will be able to discern the nature of urban morphology and determine a more precise estimate of site size, while electrical resistivity tomography combined with a programme of coring will be able to provide information about the depth of the lower town currently buried under the alluvium of the Konya plain. Such studies are planned for upcoming seasons, which hopefully will provide a higher-resolution picture than the initial image of a newly discovered Bronze and Iron Age capital city offered here.
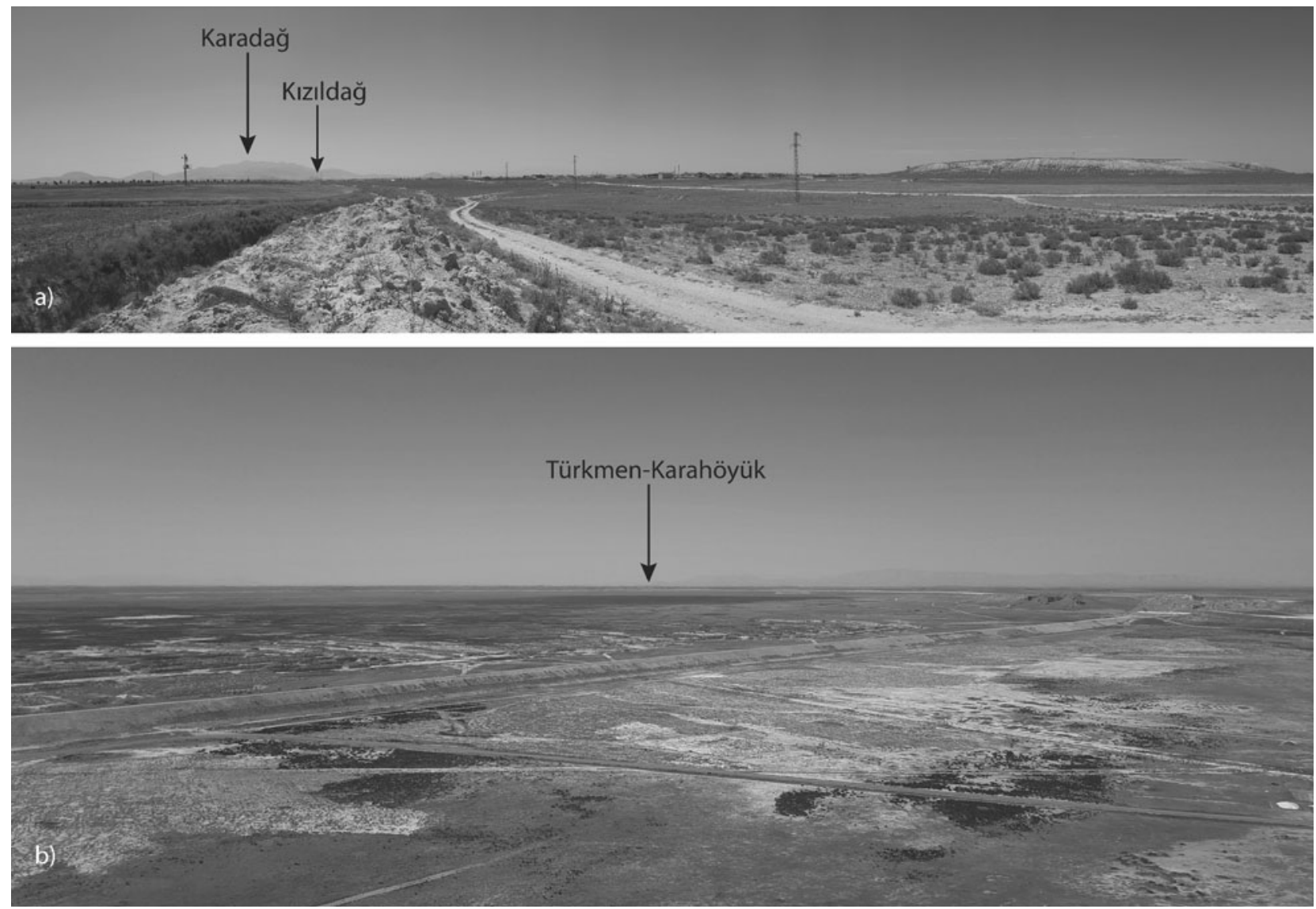

Fig. 18. (a) View of Karadă̆ and Kızlda $\breve{g}$ from the findspot of TÜRKMEN-KARAHÖYÜK 1; (b) view of TürkmenKarahöyük from the 'throne monument' of Kizlldăg (photographs by James Osborne). 


\section{Acknowledgements}

The Türkmen-Karahöyük Intensive Survey Project operates under the survey permit of the Konya Regional Archaeological Survey Project, which is generously issued by the Turkish Ministry of Culture and Tourism. Funding for TISP has been provided by the Oriental Institute of the University of Chicago. In addition to the authors, TISP team members include Fadime Arslan, Anna Berlekamp, Ashley Cercone, Osman Dengiz, Suay Erkuşöz, Ebru İncaman, Nursaç Kaya, Anthony Lauricella and Su Ün.
Turkish government representative Muzzaffer Saçkesen was helpful and supportive in every way, as were the staff of the Konya Archaeological Museum. Oya Topcuoğlu of Northwestern University kindly offered her expertise on Middle Bronze Age seals and Susan Kidwell and Jacob Waldbauer of the University of Chicago's Department of Geophysical Sciences aided with the identification of the stone used for the TÜRKMEN-KARAHÖYÜK 1 inscription. Finally, we extend our gratitude to the villagers of Türkmen-Karahöyük for their kindness and hospitality.

\section{Bibliography}

Akçay, A. 2014: 'Tabal ülkesinin tarihsel süreci üzerine bir değerlendirme' Tarih Íncelemeleri Dergisi 29.1: 37-58. https://doi.org/10.18513/egetid.69160

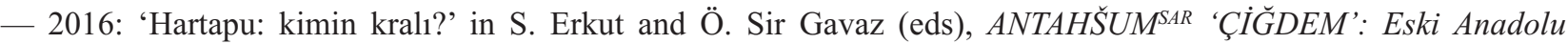
Araştırmalarına ve Hititlere Adanmış Bir Hayat: Ahmet Ünal Armă̆anı. Istanbul, Arkeologi ve Sanat Yayınları: 9-24

Akurgal, E. 1955: Phrygische Kunst. Ankara, Türk Tarih Kurumu Basımevi

Alp, S. 1968: Zylinder- und Stempelsiegel aus Karahöyük bei Konya. Ankara, Türk Tarih Kurumu Basımevi

Arnhold, S. 2009: Kusakli-Sarissa 4: das hethitische Gebäude E auf der Akropolis von Kusakli-Sarissa: Untersuchungen zum Baubefund und zum Fundmaterial 1. Rahden, Leidorf

Aro, S. 2003: 'Art and architecture' in H.C. Melchert (ed.), The Luwians. Leiden, Brill: 281-337

Atici, L., Kulakoğlu, F., Barjamovic, G., Fairbairn, A. (eds) 2014: Current Research at Kültepe-Kanesh: An Interdisciplinary and Integrative Approach to Trade Networks, Internationalism, and Identity. Atlanta, Lockwood Press/American Schools of Oriental Research. https://doi.org/10.2307/j.ctvvnd58

Aydın, A. 2015: Ovaören 2012 Kazı Sezonu Orta Tunç Çă̆ı Seramik Buluntuları. MA thesis, Gazi Üniversitesi

Bachhuber, C. 2015: Citadel and Cemetery in Early Bronze Age Anatolia. Sheffield/Bristol, Equinox

Bahar, H. 2019: 'Some remarks on the Early and Middle Iron Age pottery and settlements in the Konya region' in Ç. Maner (ed.), Crossroads: Konya Plain from Prehistory to the Byzantine Period/Kavşaklar: Prehistorik Çăg'dan Bizans Dönemine Konya Ovast. Istanbul, Ege Yayınları: 207-21

Bahar, H., Koçak, Ö. 2004: Eskiçă̆ Konya Araştırmaları 2: Neolitik Çă̆’dan Roma Dönemi Sonuna Kadar. Istanbul, Kömen Yayınları

Baird, D. 1999: 'Konya Plain Survey, central Anatolia' Anatolian Archaeology 5: 13-14

Baird, D., Carruthers, D., Fairbairn, A., Pearson, J. 2011: 'Ritual in the landscape: evidence from Pınarbaşı in the seventhmillennium cal. BC Konya plain’ Antiquity 85: 380-94. https://doi.org/10.1017/s0003598x0006782x

Baird, D., Fairbairn, A., Martin, L. 2017: 'The animate house: the institutionalization of the household in Neolithic central Anatolia' World Archaeology 49.5: 753-76. https://doi.org/10.1080/00438243.2016.1215259

Barjamovic, G. 2011: A Historical Geography of Anatolia in the Old Assyrian Colony Period. Copenhagen, Museum Tusculanum Press

— 2019: 'Silver, markets and long-distance trade in the Konya region, 2400-1700 BCE' in Ç. Maner (ed.), Crossroads: Konya Plain from Prehistory to the Byzantine Period/Kavşaklar: Prehistorik Çă̆’dan Bizans Dönemine Konya Ovast. Istanbul, Ege Yayınlar1: 71-81

Blegen, C.W., Caskey, J.L., Rawson, M., Sperling, J. 1950: Troy 1: General Introduction: The First and Second Settlements. Princeton, Princeton University Press

Bryce, T. 2012: The World of the Neo-Hittite Kingdoms: A Political and Military History. Oxford, Oxford University Press

d'Alfonso, L. 2012: 'Tabal: an out-group definition in the first millennium BC' in G.B. Lanfranchi, D.M. Bonacossi, C. Pappi, S. Ponchia (eds), Leggo! Studies Presented to Mario Fales on the Occasion of His 65th Birthday. Wiesbaden, Harrassowitz: 173-94

- 2014: 'The kingdom of Tarhuntassa: a reassessment of its timeline and political significance' in P. Taracha (ed.), Proceedings of the Eighth International Congress of Hittitology: Warsaw, 5-9 September 2011. Warsaw, Wydawnictwo Agade: 221-39

— 2019: 'War in Anatolia in the post-Hittite period: the Anatolian hieroglyphic inscriptions of Topada revised' Journal of Cuneiform Studies 71: 133-52. https://doi.org/10.1086/703857 
Dinçol, A.M., Yakar, J., Dinçol, B., Taffet, A. 2000: 'The borders of the appanage kingdom Tarhuntašša: a geographical and archaeological assessment' Anatolica 26: 1-29. https://doi.org/10.2143/ana.26.0.2015493

Dupré, S. 1983: Porsuk 1: la céramique de l'âge du bronze et de l'âge du fer. Paris, Editions Recherche sur les Civilisations

Efe, T. 2007: 'The theories of the "Great Caravan Route" between Cilicia and Troy: the Early Bronze Age III period in inland western Anatolia' Anatolian Studies 57: 47-64. https://doi.org/10.1017/s0066154600008498

Ergürer, H. 2016: Niğde Kınık Höyük Demir Çă̆ı Seramikleri. PhD thesis, Atatürk University

Fischer, F. 1963: Die hethitische Keramik von Boğazköy. Stuttgart, Kohlhammer

Forlanini, M. 2017: 'South central: the Lower Land and Tarhuntašša' in M. Weeden and L.Z. Ullman (eds), Hittite Landscape and Geography. Leiden/Boston, Brill: 239-52

French, D.H. 1970: 'Notes on site distribution in the Çumra area' Anatolian Studies 20: 139-48. https://doi.org/10.2307/3642592

- 1998: Canhasan Sites 1: Canhasan 1: Stratigraphy and Structures. London, British Institute of Archaeology at Ankara. https://www.jstor.org/stable/10.18866/j.ctt1pc5hck

- 2005: Canhasan Sites 2: Canhasan 1: The Pottery. London, British Institute of Archaeology at Ankara. https://www.jstor.org/stable/10.18866/j.ctt1n7qjxg

Fuchs, A. 1994: Die Inschriften Sargons II. aus Khorsabad. Göttingen, Cuvillier Verlag

Genz, H. 2000: 'Die Eisenzeit in Zentralanatolien im Lichte der keramischen Funde vom Büyükkaya in Bogazköy/Hattuša’ TÜBA-AR 3: 35-54. https://doi.org/10.22520/tubaar.2000.0003

— 2004: Büyükkaya 1: die Keramik der Eisenzeit: Fund aus den Grabungskampagnen 1993 bis 1998 (BoğazköyHattuša, Ergebnisse der Ausgrabungen 21). Mainz, von Zabern

— 2006: 'Die eisenzeitliche Besiedlung im Bereich der Grabungen am mittleren Büyükkale-Nordwesthang 1998-2000' in J. Seeher (ed.), Boğazköy-Berichte 8: Ergebnisse der Grabungen an den Ostteichen und am mittleren Büyükkale-Nordwesthang in den Jahren 1996-2000. Mainz, von Zabern: 98-158

- 2007: 'Late Iron Age occupation on the northwest slope at Boğazköy' in A. Çilingiroğlu, A. Sagona (eds), Anatolian Iron Ages 6: The Proceedings of the Sixth Anatolian Iron Ages Colloquium Held at Eskişehir, 16-20 August 2004. Leuven, Peeters: 135-51

Glatz, C. 2009: 'Empire as network: spheres of material interaction in Late Bronze Age Anatolia' Journal of Anthropological Archaeology 28: 127-41. https://doi.org/10.1016/j.jaa.2008.10.003

Goedegebuure, P., van den Hout, T., Osborne, J., Massa, M., Bachhuber, C., Şahin, F. 2020: 'TÜRKMENKARAHÖYÜK 1: a new Hieroglyphic Luwian inscription from Great King Hartapu, son of Mursili, conqueror of Phrygia’ Anatolian Studies 2020: 29-43

Güneri, A.S. 1987: 'Orta Anadolu höyükleri 1986' Araştırma Sonuçları Toplantası 5.2: 77-103

Gunter, A. 1991: The Gordion Excavations Final Reports 3: The Bronze Age. Philadelphia, University of Pennsylvania Museum of Archaeology and Anthropology

Hawkins, J.D. 1992: 'The inscriptions of Kızıldağ and the Karadağ in the light of the Yalburt inscription' in H. Otten (ed.), Hittite and Other Anatolian and Near Eastern Studies in Honour of Sedat Alp. Ankara, Türk Tarih Kurumu Basimevi: 259-74

- 2000: Corpus of Hieroglyphic Luwian Inscriptions 1: Inscriptions of the Iron Age. Berlin/New York, de Gruyter

Highcock, N., Crabtree, P., Campana, D.V., Capardoni, M., Lanaro, A., Matessi, A., Miller, N.F., Strosahal, P., Trameri, A. d'Alfonso, L. 2015: 'Kınık Höyük: a new archaeological project in southern Cappadocia' in S. Steadman, G. McMahon (eds), The Archaeology of Anatolia: Recent Discoveries (2011-2014). Newcastle, Cambridge Scholars Press: $98-127$

Hodder, I. (ed.) 2005: Inhabiting Çatalhöyük: Reports from the 1995-99 Seasons. London/Cambridge, British Institute at Ankara/McDonald Institute for Archaeological Research. https://www.jstor.org/stable/10.18866/j.ctt1pk875f

- (ed.) 2014: Çatalhöyük Excavations: The 2000-2008 Seasons. London/Los Angeles, British Institute at Ankara/Cotsen Institute of Archaeology. https://www.jstor.org/stable/10.18866/j.ctt1pk872w

Karauğuz, G., Bahar, H., Kunt, H.İ. 2002: 'Kızıldağ üzerine yeni bazı gözlemler' TÜBA-AR 5: 7-32. https://doi.org/10.22520/tubaar.2002.0002

Kealhofer, L., Grave, P., Bahar, H., Marsh, B. 2015: 'Between the states: Iron Age interaction in southwestern Anatolia' Journal of Archaeological Science: Reports 3: 342-57. https://doi.org/10.1016/j.jasrep.2015.05.023

Kuzucuoğlu, C. 2019 'Geomorphological landscapes in the Konya plain and surroundings' in C. Kuzucuoğlu, A. Çiner, N. Kazanc1 (eds), Landscapes and Landforms of Turkey. Cham, Springer: 353-68. https://doi.org/10.1007/978-3030-03515-0_17 
Lloyd, S., Gökçe, N. 1951: 'Excavations at Polatli: a new investigation of second and third millennium stratigraphy' Anatolian Studies 1: 21-75. https://doi.org/10.2307/3642358

Maner, Ç. 2019: 'Networks, crossroads and interconnections in the Ereğli plain during the Bronze and Iron Ages' in Ç. Maner (ed.), Crossroads: Konya Plain from Prehistory to the Byzantine Period/Kavşaklar: Prehistorik Çăg'dan Bizans Dönemine Konya Ovast. Istanbul, Ege Yayınlar1: 83-106

Massa, M., Bachhuber, C., Şahin, F., Bostanc1-Kolankaya, N., Tuna, Y. 2019: 'The Konya Regional Archaeological Survey Project: the 2017 and 2018 field seasons' Anatolica 45: 159-80. https://doi.org/10.2143/ANA.45.0.3287005

Massa, M., Bachhuber, C., Şahin, F., Erpehlivan, H., Osborne, J., Lauricella, A.J. 2020: ‘A landscape-oriented approach to urbanisation and early state formation on the Konya and Karaman plains, Turkey' Anatolian Studies 70: 45-75

Massa, M., Palmisano, A. 2018: 'Change and continuity in the long-distance exchange networks between western/central Anatolia, northern Levant and northern Mesopotamia, c. 3200-1600 BCE' Journal of Anthropological Archaeology 49: 65-87. https://doi.org/10.1016/j.jaa.2017.12.003

Matessi, A. 2016: 'The making of Hittite imperial landscapes: territoriality and balance of power in south-central Anatolia during the Late Bronze Age' Journal of Ancient Near Eastern History 3.2: 117-62. https://doi.org/10.1515/janeh2017-0004

Matessi, A., Tomassini Pieri, B.M. 2018: 'South-central: archaeology' in M. Weeden, L. Ullmann (eds), Hittite Landscape and Geography. Leiden/Boston, Brill: 89-105

Matsumura, K. 2005: Die eisenzeitliche Keramik in Zentralanatolien aufgrund der Grundlage der Ausgrabung von Kaman-Kalehöyük. PhD thesis, Freie University

Mellaart, J. 1955: 'Iron Age pottery from southern Anatolia' Belleten 19.74: 115-36

— 1958: 'Second millennium pottery from the Konya plain and neighbourhood' Belleten 22.87: 311-45

— 1963: 'Early cultures of the south Anatolian plateau, II: the Late Chalcolithic and Early Bronze Ages in the Konya plain' Anatolian Studies 13: 199-236. https://doi.org/10.2307/3642494

Momigliano, N., Greaves, A., Hodos, T., Aksoy, B., Brown, A., Kibaroğlu, M., Carter, T. 2011: 'Settlement history and material culture in southwest Turkey: report on the 2008-2010 survey at Çaltılar Höyük (northern Lycia)' Anatolian Studies 61: 61-121. https://doi.org/10.1017/s0066154600008796

Omura, S. 1991: Anadolu'da III: Alişar Seramiği. PhD thesis, Ankara University

Orthmann, W. 1963: Frühe Keramik von Boğazköy: aus den Ausgrabungen am Nordwesthang von Büyükkale. Stuttgart, Kohlhammer

Osborne, J.F. 2013: 'Sovereignty and territoriality in the city-state: a case study from the Amuq valley, Turkey' Journal of Anthropological Archaeology 32: 774-90. https://doi.org/10.1016/j.jaa.2013.05.004

- 2017: 'Exploring the lower settlements of Iron Age capitals in Anatolia and Syria' Antiquity 91.355: 90-107. https://doi.org/10.15184/aqy.2016.254

- forthcoming: The Syro-Anatolian City-States: An Iron Age Culture. Oxford/New York, Oxford University Press

Osborne, J.F., Karacic, S. 2017: 'Urbanism beyond the acropolis: the Tayinat Lower Town Project surface survey, 20142015' Anatolica 43: 37-70

Özgüç, N. 1968: Kanis Karumu Ib Katı Mühürleri ve Mühür Basklları/Seals and Seal Impressions of Level Ib from Karum Kanish. Ankara, Türk Tarih Kurumu Basımevi

— 2015: Acemhöyük-Burušhaddum 1: Cylinder Seals and Bullae with Cylinder Seal Impressions. Ankara, Türk Tarih Kurumu Basimevi

Özgüç, T. 1950: Kültepe Kazısı Raporu 1948. Ankara, Türk Tarih Kurumu Basımevi

Parzinger, H., Sanz, R. 1992: Die Oberstadt von Hattusa. Hethitische Keramik aus dem zentralen Tempelviertel: Funde aus den Grabungen 1982-1987. Berlin, Mann

Postgate, N., Thomas, D. (eds) 2007: Excavations at Kilise Tepe 1994-1998: From Bronze Age to Byzantine in Western Cilicia 1: Text. London/Cambridge, British Institute at Ankara/McDonald Institute for Archaeological Research. https://www.jstor.org/stable/10.18866/j.ctt1pk3jtc

Ramsay, W.M., Bell, G.L. 1909: The Thousand and One Churches. London, Hodder and Stoughton

Rose, C.B. 2012: 'Introduction: the archaeology of Phrygian Gordion' in C.B. Rose (ed.), The Archaeology of Phrygian Gordion, Royal City of Midas. Philadelphia, University of Pennsylvania Museum of Archaeology and Anthropology: 1-19. https://doi.org/10.9783/9781934536599.1

- 2017: 'Fieldwork at Phrygian Gordion, 2013-2015' American Journal of Archaeology 121.1: 135-78. https://doi.org/10.3764/aja.121.1.0135

Rose, C.B., Darbyshire, G. (eds) 2011: The New Chronology of Iron Age Gordion (Gordion Special Studies). Philadel- 
phia, University of Pennsylvania Museum of Archaeology and Anthropology

Şahin, F. 2014: 'Küllüoba Orta Tunç Çağı'na geçiş dönemi: mimarisi ve çanak çömleği’ Arkeometri Sonuçları Toplantısı 30.1: 39-54

— 2015: 'Küllüoba'da erken Tunç Çağı III döneminde kalınlaştırılmış dudaklı (bead-rim) kaselerin ortaya çıkışı ve gelişimi’ Colloquium Anatolicum/Anadolu Sohbetleri 14: 100-19

Şahoğlu, V. 2005: 'The Anatolian Trade Network and the Izmir region during the Early Bronze Age' Oxford Journal of Archaeology 24.4: 339-61. https://doi.org/10.1111/j.1468-0092.2005.00240.x

Sams, G.K. 1994: The Gordion Excavations, 1950-1973: Final Reports 4: The Early Phrygian Pottery. Philadelphia, University of Pennsylvania Museum of Archaeology and Anthropology

Sams, G.K., Voigt, M.M. 2011: 'In conclusion' in C.B. Rose, G. Darbyshire (eds), The New Chronology of Iron Age Gordion. Philadelphia, University of Pennsylvania Museum of Archaeology and Anthropology: 155-68

Schoop, U.-D. 2011: 'Hittite pottery: a summary' in H. Genz, D.P. Mielke (eds), Insights into Hittite History and Archaeology. Leuven, Peeters: 241-73

Şenyürt, S.Y., Akçay, A. 2018: 'TOPADA yazıtına farklı bir bakış: geç Hitit döneminde orta Anadolu'da güç dengeleri' TÜBA-AR 22: 95-117. https://doi.org/10.22520/tubaar.2018.22.006

Summers, G.D. 1994: 'Grey Ware and the eastern limits of Phrygia' in A. Çilingiroğlu, D.H. French (eds), Anatolian Iron Ages 3: The Proceedings of the Third Anatolian Iron Ages Colloquium Held at Van, 6-12 August 1990. Ankara, British Insitute of Archaeology at Ankara: 241-52. https://www.jstor.org/stable/10.18866/j.ctt1pc5gxc

— 2009: 'Between Urartu and Phrygia: the north-central Anatolian plateau in the Iron Age' in H. Sağlamtimur, E. Abay (eds), Studies in Honour of Altan Çilingiroğlu: A Life Dedicated to Urartu on the Shores of the Upper Sea. Istanbul, Arkeoloji ve Sanat: 657-71

Toteva, G.D. 2007: Local Cultures of Late Achaemenid Anatolia. PhD thesis, University of Minnesota

Ur, J. 2003: 'CORONA satellite photography and ancient road networks: a northern Mesopotamian case study' Antiquity 77: 102-15. https://doi.org/10.1017/s0003598x00061391

- 2010: Urbanism and Cultural Landscapes in Northeastern Syria: The Tell Hamoukar Survey, 1999-2001. Chicago, Oriental Institute of the University of Chicago

Ur, J., Karsgaard, P., Oates, J. 2011: 'The spatial dimensions of early Mesopotamian urbanism: the Tell Brak suburban survey, 2003-2006' Iraq 73: 1-19. https://doi.org/10.1017/s0021088900000061

von der Osten, H.H. 1937: The Alishar Hüyük Seasons of 1930-32 2. Chicago, University of Chicago Press 